\title{
Kv3.3b: A Novel Shaw Type Potassium Channel Expressed in Terminally Differentiated Cerebellar Purkinje Cells and Deep Cerebellar Nuclei
}

\author{
Debra S. Goldman-Wohl, ${ }^{a}$ Emily Chan, Douglas Baird, ${ }^{\mathrm{b}}$ and Nathaniel Heintz \\ Howard Hughes Medical Institute, The Rockefeller University, New York, New York 10021
}

\begin{abstract}
A two-step hybridization/subtraction procedure was employed to isolate markers for the later stages of Purkinje cell differentiation. From this screen, a novel Shaw potassium channel cDNA (Kv3.3b) was identified that is developmentally regulated. Expression of this channel is highly enriched in the brain, particularly in the cerebellum, where its expression is confined to Purkinje cells and deep cerebellar nuclei. Sequence analysis revealed that it is an alternatively spliced form of the mouse Kv3.3 gene, and that the previously reported Kv3.3 mRNA (Ghanshani et al., 1992) is not expressed in cerebellum. Expression of the Kv3.3b mRNA begins in cerebellar Purkinje cells between postnatal day 8 (P8) and P10 and continues through adulthood, coinciding with elaboration of the mature Purkinje cell dendritic arbor. The timing of expression of Kv3.3b mRNA is maintained in mixed, dissociated primary cerebellar cell culture. These results suggest that the $\mathrm{Kv}^{3.3 \mathrm{~b} \mathrm{~K}} \mathrm{~K}^{+}$channel function is restricted to terminally differentiated Purkinje cells, and that analysis of the mechanisms governing its expression in vivo and in vitro can reveal molecular mechanisms governing Purkinje cell differentiation.
\end{abstract}

[Key words: Purkinje cells, deep nuclei, Shaw, potassium channel, terminal differentiation, development]

The development of the mammalian CNS is programmed by a complex series of genetic and epigenetic events that regulate the differentiation of neuronal and glial cell types. Although one can expect that certain molecular mechanisms that regulate development in the CNS will be employed broadly to program specific stages of differentiation in many different neuronal cell types, these mechanisms must be precisely regulated by the microenvironment in which a given neuron is developing. For

\footnotetext{
Received May 27, 1993; revised Aug. 18, 1993; accepted Aug. 26, 1993.

This work was supported by HHMI and by NIH Grant NS08815-02 to D.S.G.W. and NIH MSTP Fellowship GM07739-14 to E.C. We are very grateful to Monique Thomasset for her gift of the calbindin clone from which we made the riboprobes and to Sylvia Christakos for her gift of the calbindin- $D_{28 k}$ antibody. We also thank Marius Sudol for his gift of an actin clone from which we made probes for Northerns. In addition, we thank Dr. Carol Mason for help with the cell cultures and Julie Miwa for critical reading of the manuscript and useful discussions.

Correspondence should be addressed to Dr. Nathaniel Heintz, Howard Hughes Medical Institute, The Rockefeller University, 1230 York Avenue, Box 260, New York, NY 10021.

aPresent address: The Lautenberg Center for General and Tumor Immunology, Hebrew University - Hadassah Medical School, Ein Kerem, Jerusalem, Israel.

rPresent address: Department of Anatomy and Neurobiology, Medical College of Pennsylvania, 3200 Henry Avenue, Philadelphia, PA 19129.

Copyright $(C) 1994$ Society for Neuroscience $0270-6474 / 94 / 140511-12 \$ 05.00 / 0$
}

example, one might expect that proper temporal regulation of gene products involved in synaptogenesis is required for establishment of proper neuronal circuitry, and that this regulation may be achieved through mechanisms that impinge directly on individual neurons. Our interest is both to identify general subprograms for neuronal differentiation and to discover how these programs are epigenetically regulated in specific neuronal cell types. To investigate these processes, we have chosen to focus on mechanisms regulating development of the mammalian cerebellum.

Cerebellar Purkinje cells provide the sole cerebellar efferent pathway. Since the initial description of cerebellar Purkinje cell development by Ramon y Cajal (1911), analysis of Purkinje cell development under a wide variety of experimental conditions has established that differentiation of these neurons involves complcx interactions between intrinsic and extrinsic programs. Purkinje cells originate from the primitive ependymal layer, and in the mouse they become postmitotic by embryonic day 13 (E13) (Uzman, 1960; Miale and Sidman, 1961). Three general phases of Purkinje cell differentiation have been recognized. Until approximately birth, Purkinje cells are small and fusiform, and constitute a multilayered band several cells thick in the cerebellar anlage (Ramon y Cajal, 1911; Uzman, 1960). They then organize themselves into a discrete monolayer forming the boundary between the internal granule layer and the molecular layer in the developing cerebellar cortex (Miale and Sidman, 1961). In this second stage of differentiation, Purkinje cells are multipolar, possessing numerous somatic processes (Ramon y Cajal, 1911). In the final phase of their differentiation, coincident with migration of cerebellar granule cells from the external germinal layer into the internal granular layer during the second and third postnatal weeks, the elaborate dendritic arbor that is the anatomical hallmark of mature cerebellar Purkinje cells is formed. It is during this time that Purkinje cells undergo extensive synaptogenesis with their presynaptic excitatory partners, the cerebellar granule neurons (Herndon et al., 1981).

Examination of Purkinje cell differentiation in the absence of cerebellar granule neurons has demonstrated that Purkinje cells are formed in the absence of granule cells, but that the final stage of Purkinje cell development is critically dependent upon granule cell interaction. Neurologic mutant mouse strains in which granule cells fail to differentiate and descend into the internal granule layer exhibit gross abnormalities of the Purkinje cell dendritic arbor, and fail to develop the characteristic spiny branchlets that characterize normal Purkinje cells (Sidman, 1968; Hirano and Dembitzer, 1973; Rakic and Sidman, 1973a,b; Sotelo, 1975; Bradley and Berry, 1978). Destruction of the devel- 


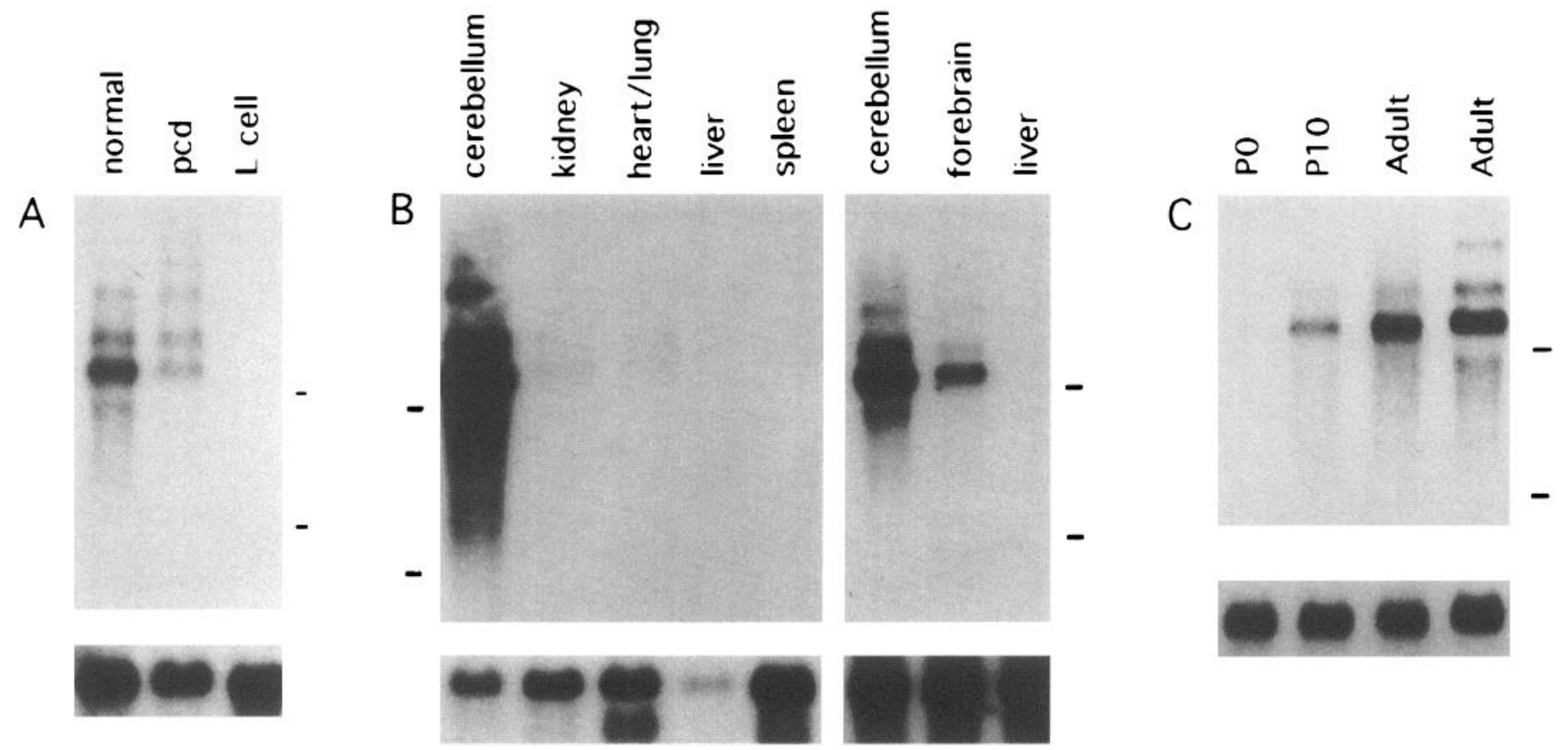

Figure 1. A, Northern blot analysis of $5 \mu \mathrm{g}$ each of total adult cerebellar RNA, adult $p c d / p c d$ RNA, and L-cell RNA with the pcd8 probe (top) or an actin probe (bottom). Tick marks indicate the positions of the $28 \mathrm{~S}$ and $18 \mathrm{~S}$ ribosomal RNAs. B, Northern blot analysis of adult mouse tissues. Two micrograms of polyA + RNA from adult cerebellum, kidney, heart/lung, liver, spleen, cerebellum, forebrain, and liver were analyzed by Northern blot with the $940 \mathrm{bp}(8118)$ probe. The blot was then stripped and reprobed with an actin probe (bottom). Tick marks indicate the position of the $28 \mathrm{~S}$ and $18 \mathrm{~S}$ ribosomal RNAs. $C$, Northern blot analysis of mouse cerebellum at different postnatal ages. Two micrograms of polyA ${ }^{+} \mathrm{RNA}$ from mouse cerebellum at P0, P10, and adult and $3 \mu \mathrm{g}$ of polyA ${ }^{+}$RNA from adult mouse cerebellum (far right lane) were analyzed by Northern blot using the 940 bp clone $(8118)$ as a probe $(t o p)$. The blot was then stripped and reprobed with GAPDH (bottom). The tick marks indicate the positions of the $28 \mathrm{~S}$ and $18 \mathrm{~S}$ ribosomal RNAs.

oping external germinal layer by $\mathrm{x}$-irradiation (Berry and Bradley, 1976), viral infection (Herndon et al., 1971a,b), or cytotoxic drug treatment (Shimada and Langman, 1970; Woodward et al., 1975) results in stunted and malformed Purkinje cell dendritic arbors and the absence of spiny branchlets. Recent experiments in which purified embryonic Purkinje cell precursors were cultured in the presence or absence of cerebellar granule cells also demonstrate that development of mature Purkinje cell morphology, in particular the presence of dendritic spines that are indistinguishable from those present in vivo, occurs in vitro only in the presence of differentiating cerebellar granule cells (C. Baptista, M. E. Hatten, and C. Mason, unpublished observations). Since dendritic spines are the sites of synapse formation and specialization between the Purkinje cell dendritic arbor and the granule cell parallel fibers, one might surmise that epigenetic mechanisms that control the final stages of Purkinje cell differentiation are critical for proper construction of mature cerebellar circuitry.

One approach toward definition of the precise molecular mechanisms underlying the epigenetic regulation of this stage of Purkinje cell differentiation is the biochemical and molecular genetic analysis of gene expression. Thus, dissection of the signal transduction pathways that control the cell type and temporal specificity of expression of genes activated in the terminal stages of Purkinje cell differentiation can reveal mechanisms critical for these events in Purkinje cells that may also play important roles in other neuronal cell types. Furthermore, the identification of genes whose expression is limited to terminally differentiated Purkinje cells implicates their cognate gene products in mature Purkinje cell function. In this study, we report the identification of a novel potassium channel cDNA whose mRNA is expressed specifically in Purkinje cells and in deep cerebellar nuclei. The temporal pattern of expression of this gene in developing cerebellar cortex, and the precise distribution of the mRNA across the Purkinje cell population suggest that its expression may be responsive to the epigenetic mechanisms that regulate the timing of Purkinje cell terminal differentiation. Cellspecific and temporally correct expression of this $\mathrm{K}^{+}$channel cDNA is observed in mixed dissociated cerebellar cell cultures. These results strongly support a role for this $\mathrm{K}^{+}$channel in mature Purkinje cell function, and demonstrate that expression of this gene in primary cell culture may be useful for definition of mechanisms regulating Purkinje cell terminal differentiation.

\section{Materials and Methods}

Mice. $p c d$ mice $\mathrm{B} 6 \mathrm{C} 3 \mathrm{Fe}-\mathrm{a} / \mathrm{a}-p c d$ and their littermates were purchased from The Jackson Laboratory, Bar Harbor, Maine. All other mice were bred and housed at the Laboratory Animal Research Center at the Rockefeller University.

$m R N A$ preparation. Total RNA was isolated using the acid guanidinium thiocyanate-phenol-chloroform method (Chomczynski and Sacchi, 1987). PolyA+ RNA was prepared using an oligo-dT cellulose (Bethesda Research Laboratories, Gaithersburg, MD) column (Aviv and Leder, 1972). When total RNA instead of mRNA was used for Northern analysis, total RNA was isolated by $\mathrm{LiCl}$ precipitation (Cathala, 1983).

Northern analysis. RNAs were run in 1\% agarose, $1 \times$ MOPS buffer, $1.1 \%$ formaldehyde gels and visualized by ethidium bromide staining. The gels were transferred overnight onto Gene Screen Plus membranes (Dupont, Inc.). Prehybridization for a minimum of half an hour and hybridization overnight were at $42^{\circ} \mathrm{C}$ in $50 \%$ formamide, $1 \mathrm{~m}$ sodium chloride, $1 \%$ SDS, and $100 \mu \mathrm{g} / \mathrm{ml}$ boiled sheared salmon sperm DNA. Probe synthesis was done by random hexanucleotide labeling (Feinberg and Vogelstein, 1983); $1 \times 10^{6} \mathrm{cpm} / \mathrm{ml}$ of boiled probe was added in the hybridization buffer. Blots were washed to a final stringency of either 

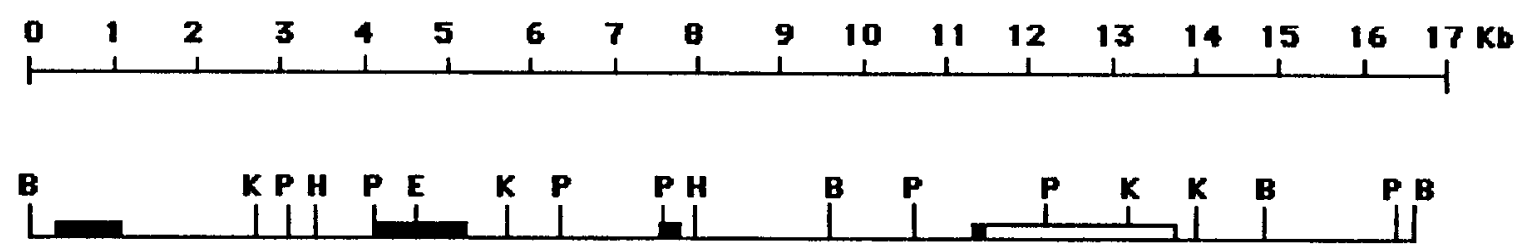

ATG CTC AGT TCA GTG TGC GTC TGG TCG TTC CGC GGG TGC CAG GGG ACC GGC AAG CAG CAG CCT CAG CCG GTG CCA ACG CCG CAG CCG CCT GAG TCC TCA CCG CCG CCT CTG CCG CCG CCG

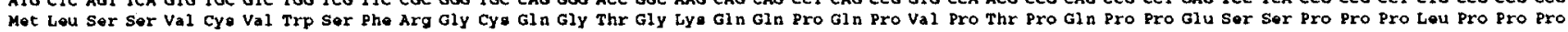

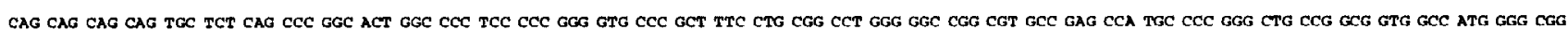

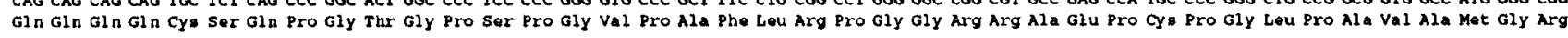
CAC GGC GGC GGC GGC GGC GAC AGC GGT AAG ATC GTG ATC AAC GTG GGC GGC GTG CGC CAT GAG ACG TAC CGC TCC ACG TTG CGC ACC CTG CCA GGG ACC AGA CTG GCC GGG CTG ACC GAG Hi. Gly Gly Gly Gly Gly Aap Ser Gly Lye Ile Val Ile Aan Val Gly Gly Vol Arg Hie Glu Thy Tyr Arg ser Thr Leu Arg Thx Leu Pro Gly Thr Arg Lou Ala Gly Leu Thr Glu

CCC GAG GCG GCC GCO CGC TTT GAC TAC GAC CCG GGC ACG GAC GAG TTC TTC TTC GAC CGT CAC CCG GGC GTC TTC GCC TAC GTG CTC AAC TAC TAC CGC ACC CGC AAA CTG CAC TGC CCO Pro Glu Ala Ala Ala Arg Phe Aap Tyr Aap pro Gly Thr Aap Glu Phe Phe Pho Aap arg His Pro Gly val phe Ala Tyr val Leu Aan Tyr Tyr Arg Thr Gly Lya lou Hia Cye pro

120

360

480

600

GCC GAC GTG TGC GGG CCG CTC TTC GAG GAC GAG CTG GGC TTC TGG GGC ATA GAC GAG ACG GAC GTG GAG GCC TGC TGC TGG ATG ACC TAT CGC CAG CAC CGT GAC GCT GAG GAG GCA CTG Ala Aap Val Cya Gly Pro Leu Phe Glu Glu Glu Leu Gly Phe Trp Gly Ilo Aap Glu Thr Asp Val Glu Ala Cyo Cya Trp Met Thr Tyr Arg Gln hi Arg Aap Ala Glu Glu Ala Leu

GAC TCT TTC GAG GCC CCG GAC TCC TCG GCC AAC GCC AAC GCC AAC GCC GGA GGC GCG CAC GAT GCG GGA CTG GAC GAC GAG GCG GGA GCA GGA GGC GGC GGC CTG GAC GGG GCA GGC GOC Aep Ser phe glu Ala pro Aap Ser Ser Ala Aen Ala Aan Ala Aan Ala Gly Gly Ala Hia Aap Ala Gly Lau Aap Aap Glu Ala Gly Ala Gly Gly Gly Gly Lau Aap Gly Ala Gly Gly

GAG CTC MAG CGT CTG TGT TTT CAG GAC GCO GGC GGA GGT GCC GGA GGA CTG CCO GGO GCO GCG GGC GGC GCG GGC GGC ACC TGG TGG CGG CGC TGG CAG CCC CGT GTG TGG OCG CTT TTT Glu Lou Lyg Arg lou Cya Phe Gln Aep Ala Gly Gly Gly Ala Gly Gly Lou Pro Gly Gly Ala Gly Gly Ala Gly Gly Thr Trp Trp Arg Arg Trp Gla Pro Arg Val Trp Ala Leu Phe

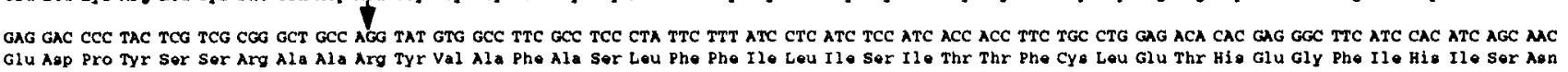
MAG ACG GTG ACG CAG GCC TCC CCA ATC CCT GGG GCT CCC CCG GAG MAT ATC ACC AAC GTG GAG GTG GAG ACG GAA CCC TTC TTG ACC TAC GTG GAA GGC GTG TGT GTG GTC TGG TTC ACC Lye Thr Val Thr Gln Ala Ser Pro Ile pro Gly Ala Pro Pro Glu Asn Ile thr Aan Val Glu val Glu Thr Glu Pro Phe Leu Thr Tyr Val Glu Gly Val Cya Val Val Trp Phe Thr

TTT GAG TTT CTC ATG CGG GTC ACC TTC TGC CCA GAT AAG GTG GAG TTT CTC AAA AGC AGC CTG AAC ATC ATC GAC TGC GTG GCC ATC TTG CCC TTC TAC TTG GAA GTG GGC CTG TCA GGT Phe Glu phe Leu Met Arg Val Thr phe Cye Pro Aap Lye Val Glu Phe Leu Ly Ser Ser Leu Aen Ile Ile Asp Cys Val Ala Ile Lau Pro Phe Tyr Lou Glu Val Gly Leu Ser Gly

CTC AGC TCC AAA GCT GCC AAG GAC GTG CTG GGC TTC CTG CGT GTC GTC CGC TTC GTG CGC ATC CTT CGT ATC TTC AAG CTG ACC CGT CAC TTC GTG GGG CTG CGT GTG CTG GGC CAC ACG Leu Ser Ser Lye Ala Ala Ly Aap Val Leu Gly Phe Lou Arg Val Val Arg Pho Val Arg Ile Leu Arg Ile Phe Lye Leu Thr Arg Hia Phe Val GlyaLeu Arg Val Leu Gly Hio Thr

CTC CGG GCC AGC ACC AAC GM TTC TTG TTA CTC ATC ATC TTC CTG GCT CTG GGG GTC CTC ATC TTT GCC ACC ATG ATC TAC TAT GCC GAA CGC ATC GGG GCT GAT CCT GAC GAC ATC CTG Leu Arg Ala Sor Thx Aen alu Phe Leu Leu Leu Il. Il. Phe Lou Ala Leu Gly Val Leu Ile Phe Ala Thr Met Ile Tyr TYr Ala Glu Arg Ile Gly Ala Aap Pro Aap Aap Ile Leu GGC TCC AAC CAC ACC TAC TTC AAG AAC ATC CCC ATC GGC TTC TGG TGG GCT GTG GTC ACC ATG ACG ACA CTG GGC TAT GGA GAC ATG TAT CCC AAG ACG TGG TCT GGG ATG CTG GTT GGG

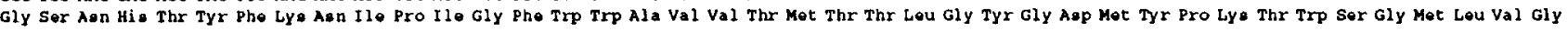

GGA CTG TGT OCC CTG GCT GGT GTG CTG ACC ATT GCC ATG CCC GTG CCT GTC ATT GTC AAC AAC TTC GGC ATG TAC TAT TCA CTG GCT ATG GCC AAG CAG MAA TTG CCA AAG AAG AAA AAC

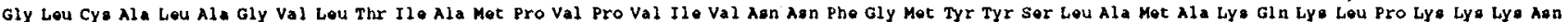

aAA CAT ATT CCC AGG CCC CCG CAG CCT GGC TCA CCC AAC TAC TEC MAG CCT GAC CCC CCG CCT CCA CCC CCA CCA CAC CCC CAC CAC GGC AGC GGT GGC ATA AGC CCA CCG CCG CCC ATC

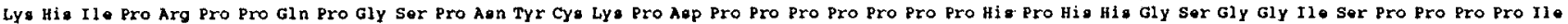

ACC CCT CCT TCC ATG GGG GTG AAT GTG GCC GGG GCC TAC CCA CCT GGA CCC CAC ACA CAC CCC GGG CTG CTC AGG GGT GGT GCT GGG GGC CTG GGA ATC ATG GGA TTG CCT CCT CTG CCA

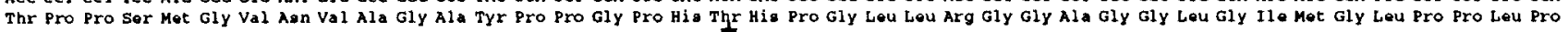
GCC CCT GGT GAG CCC TGC CCA TTG GCT CAA GAA GAG GTG ATT GAA ACC AAC AGG GCA GTA GAC CCC CGT CCC AAT GGA GAC CCT GCA GCA GCC GCA CTG GCC CAT GAG GAC IGC CCT GCC

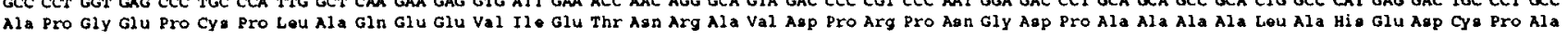
ATC GAC CAG CCA GCC ATG TCT CCA GAA GAC AAG AGC CCA ATC ACT CCC GGA AGC CGG GGT CGC TAC AGC CGG GAC CGA GCT TGC TTC CTT GTC ACA GAC TAT GCC CCT TCC CCT GAT GGC

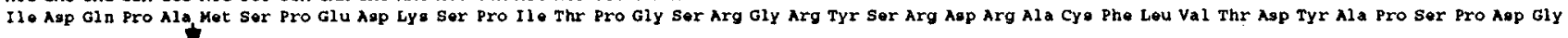
TCC ATC CGA MA GGT TAC GAG AAG TCC CGC AGC CTG AGC AGC ATT GTG GGC CTG AGC GGC GTG TCC CTG CGC CTC GCG CCC CTC GCC ACC CCC CCT GGC TCT CCC CGG GCC ACG CGC CGA Ser I1. Arg Lye Gly Tyr Glu Lys Sor Arg Ser Lou Ser Sor Ilo val Gly Lou Ser Gly Val Ser Leu Arg Leu Ala Pro Lou Ala Thr Pro Pro Gly Ser Pro Arg Ala Thr Arg Arg GCT CCC CCG ACC CTG CCC TCC ATC CTC TAG CGC AGC CCT CCC CCC TGT GGG GGG ACT GGG GGT GAT GGG AAG GTG AAA AGG AGC TGG GAG TAG GGC TGG GGA AAG GGT TCT TTP TTT TTT Ala Pro Pro Thr Leu Pro Ser Ile Leu

AAA AAA MAA GTC AAT AAT ATG CAA AAG AGA CGA TGC CAG CAG ACA CCC CCG GGG CCT CTC ACT CCC CAT ACA CTA GAA AAC CCA GGA TAG AGG GGG CAG GGC CGG AGC CTG TAC CCC ATC TCC CTC CCC TTT CCA AAA AAA AAA AAA AAA GCA AAC CTC AGG TCT CCA TGA GCC ATA GGA CAC CCC TCC CAT CGA CTC CTG TAA ATA ACT AAA AGC TGA TTC CAT CTT GGG GCA CCC ACT CCA GTT TGC ATG CCT CCC CGA CCC CCT CTT CAG CAA TAA GCC GCC AGG AGC TGT GTG CAA AGA GTT GGA GGG GAG GCT GCT GGG AGC CTC TAA GGT CGG AGC TAG CAT TTT TAG GGG TCT TCA GCT TGG GGG TGG GGG GGT TCT GCC AGC TGC TCT TGG GCT TGG AGG ACG CCA GCT GGT GCA TTC CAC CCA CGC CCG CCT CCA GGG ATC TGC TCC CTC TAT TCG CTG CAT GGA CTT GGC CCT CCA GGC CAG AAC CCT CTA CCC ACT GCA GTC TCC ACT CTA TCC CAA GAG GTG AGA CTA GTA CCC TAG ACT TAA GGA GAC AGA ACC TGG CAC CCT GCA CTC CCA CAC CCC ACG GAC TCC GGG GGC CCC CAC TCC TCA CCT CCA TCA CTC CAT CCA TCC CCC ACT GGC CTG GAC TGC ACC ACA GAG TTT TTC CAC TCT TCC CTT GCA CCT CCA CTC ACT TCC AGC CTT COA GGT TCT GAC AGT CCT CAA GAC CCT GAC ATT GCC TAG ACA CCC CTA TAT CCC CAA CCC CAG ACG GCC CCA ACT CCC TGA CAT CAC ACT CCT CTG TCC CCT GGC CTC TGG CGC AAG ACC TTC CCG GAC AAG CTC CGT CTG TCT GAT TAC AGA GAG CTC CCA TCC CAT TCC AGT ATT ACT GTC TAG GCA GCC CCC TCC TCA CTG CCC CCA CCC CCA CCA ACC CAT GGT GCC AAA ACA CAC TTT CTT CAT GGC GTG CGT CCT GGC AGC GCA CGA GTT GTG TGT TGC CAC TGA AAG CAA GTC TAA GAC AGG ATG GGA CCC AAT GCT AAA AGC GCT TGC TTA ATG TGC TAM GGT CCC AGG GTT CAA ACT CCA GCA

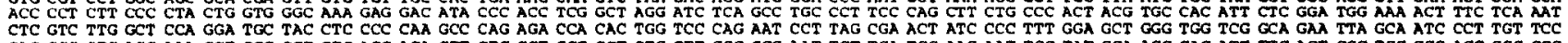

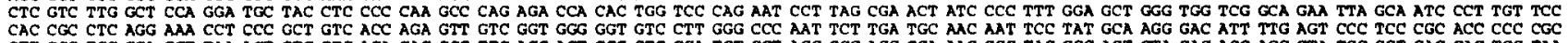
CAC CGC CTC AGG AAA CCT CCC GCT GTC ACC AGA GTT GTC GGT GGG GGT GTC CTT GGG CCC AAT TCT TGA TGC AAC AAT TCC TAT GCA AGG GAC ATT TTG AGT CCC TCC CGC ACC CCC CGC

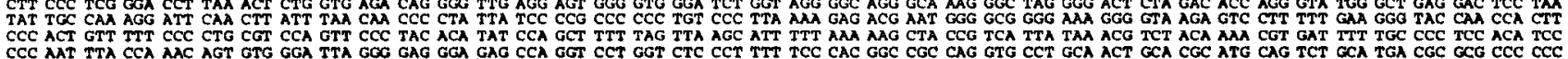
CCC ACT GTT TTT CCC CTG CGT CCA GTT CCC TAC ACA TAT CCA GCT TTT TAG TTA AGC ATT TTT AAA AAG CTA CCG TCA TTA TAA ACG TCT ACA AAA CGT GAT TTT TGC CCC TCC ACA TCC
CCC AAT TTA CCA AAC AGT GTG GGA TTA GGG GAG GGA GAG CCA GGT CCT GGT CTC CCT TTT TCC CAC GGC CGC CAG GTG CCT GCA ACT GCA CGC ATG CAG TCT GCA TGA CGC GCG CCC CCC
ACA TAC ACG ACA TAC ACA CGC ATG CGT CGC GCA CCC CTC CTG CGC TGG GGS GGG AGG CCG ACT TGG GGG CGG GGG ATG GGG AGG AAT GAT TGG CAG AGG GGA AGG GGG TCT TTC TGA ACT CAA TGG CTC CTC TCC TTC CCC ACA CAC TCA CAG CM TAA GTT TCT CTA CTT CTA GTG GGC GGA CGG GCC TAG CCT GAC CTG GCG CGG GAG GGG CTG GCC MAT GGG CGC TCT CAG GGA TGG GGG CGG GTC
CTG AGT GTG GGG GAG GGG AGG TCT GCA ACT CTG GTG CTA ATG GCG GGT CTT CCT GGC CCA CCC GCA GCA GGG AGG AMG GAG TCG GCA GGC TCT CCC CCA AGC CTC CCC CAC GCC CAC CCA
GGG TGC ATG CAC CAC CCA CGC AGA AGC TGC CGC ATG TCA ACC CTC CCC CCC ACA MAG AAA CAG TGT CAT GCC CCT TTC CAC CTG CCC TCC CAC TCC CCA GCC CAA TAA ATO ATA CCT TTT GGG TGC ATG AAC CAC CCA CGC AGA AGC TGC CGC ATG TCA ACC CTC CCC CCC

Figure 2. Genomic map of Kv3.3 gene. The restriction map was derived from the part of a cosmid that contained the Kv3.3 gene. The boxes indicate the location of the exons from our cDNAs. The 5' end of exon one was derived from the published sequence (Ghanshani et al., 1992) and from genomic sequencing. The deduced $\mathrm{Kv} 3.3 \mathrm{~b}$ cDNA sequence is shown. The arrows indicate splice sites. The solid boxed regions indicate the coding portions of the cDNA. 
SHAW (DROS PROT) KVA (rat prote $1 \mathrm{n}$ ) KSH I I IC prot RKShIIIAprot Kv3 . 3bprot KSHIIID, 1prot KSHIIID.2prot KV3. 3 pror

Consensus

SHAW (DROS PROT) Kv4 (rat protein) KSHIIICprot RKSh1 I IAprot KV3. 3 bprot KSHIIID.1prot KSHIIID.2prot KV3, 3 prot

Consensus

SHAW (DROS PROT) KV4 (rat proteln) KSH I I ICprot RKShII IAprot Kv 3.3bprot KSHI IID. 1prot KSHIIID.2prot KV 3.3 prot

Consensus

SHAW (DROS PROT) KV4 (rat protein) KsHIIICprot RKShI I IAprot Kv 3. 3bprot KSHIIID. 1 prot KSHIIJD.2prot Kv3.3 prot

Consensus

SHAW (DROS PROT) KV4 (rat protein) KSHI I ICprot RKShI IIAprot KV3.3bprot KSHI I ID. Iprot KSHIIID 2 pror Kv3.3 prot

Consensus

SHAW (DROS PROT) Kv4 (rat protein) KSH I ICprot RSHIIICprot RKShIIIAprot
KV3.3bprot KSHIIID. Iprot KSHI ID.2prot Kv3. 3 prot

Consensus

SHAW (DROS PROT) Kv4 (sat proteln) KSHI IICprot RKShIIIAprot KV3 3 3prot KSHIIID.1prot KSHIIID.2prot Kv 3 , 3 prot

Consensus

SHAW (DROS PROT) Kv4 (rat protein) KSHIIICprot RKSh I I Aprot Kv3, 3bprot KSHIIID. 1prot KSHIIID.2prot Kv3 3 prot

Consensus

SHAW (DROS PROT) KV4 (rat proteln KSHI I ICprot RKShIIIAprot Kv 3. 3bprot KSHIIID. lprot KSHIIID . 2prot Kv 3.3 prot

Consensus 作 M M . . . - . MLSSVCVWSFRGCQGTGKQQPQPVPTPQPPESSPPPLPPPQQQQCSQPGTGP SPGVPAFL-RPGGRRAEPCPGLPAVAMGRHGGGGGDSGKIVINVGGVR MLSSVCVWSF SGRQGTRKQH SQPAPTPQPP ESSP PPLLPPPQQQCAQPGTAASPAGAPLSCGPGGRRAEPCSGLPAVAMGRHGGGGGDSGKIVINVGGVR MLSSVCVWSF SGROGTRKOH SOPAPTPOPPESSP PPLL PPPOOOCAOPGTAASPAGAPLSCGPGGRRAEPC SGLPAVAMGRHGGGGGDSGKIVINVGGVR . MGRHGGGGGDSGKIVINVGGYR M.

HETYKATLKK I P - ATR LSRLTEALA - - - - NYD- - - - - - P I LN - - - EYF FDRHPGVFAQVLNYYRTGKLHYPTDVCGPLFEEELEFWGLDSNQVEPCCW HOTYRSTLRTLP -GTRLAWLAEPDAH SHFDYD--.---- - PRAD- - - EFF FDRHPGVFAHI LNYYRTGKLHCPADVCGPLYEEELAFWGIDETDVEPCCW HETYRSTLRTLP - GTRLAWLADPDGGGRPETDGGGVGSSGTSGGGGCEFF FDRHPGVFAYVLNYYRTGKLHCPADVCGPLFEEELTPWGIDETDVEPCCW LQPLPP PLSP PPRPPP LSPVPSGCF EGGAGNCSSHGGNGSDHPGGGR EF FFDRH PGVFAYVLNYYRTGKLHCPADVCGPLFEEE LA FWGI DETDV EPCCW HETYRSTLRTLP-GTRLAGLTEPEAAAR FDYD-- - - . - PGTD- - - EFF FDRH PGVFAYVLNYYRTGKLHCPADVCG PLFEEELGFWG IDETDVEACCW HETYRSTLRTLP-GTRLAGLTEPEAAARFDYD--- - - - - PGTD--- EFFFDRHPGVFAYVLNYYRTGKLHCPADVCGPLFEEELGFWGIDETDVEACCW HETYRSTLRTLP - GTR LAGLTEPEAAARFDYD-- - - - - PGTD- - - EFFFDRH PGVFAYVLNYYRTGKLHCPADVCGPLFEEELGFWGI DETDVEACCW HETYRSTLRTLP -GTR LAGLTEPEAAAR FDYD-- - - - PGTD- - EFFFDRH PGVFAYVLNYYRTGKLHCPADVCGPLFEEELGFWGIDETDVEACCW

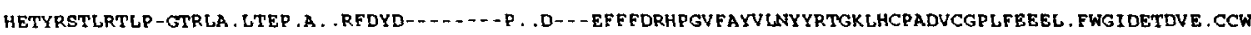

MTYTQHRDTQETLAVLDRLDLDTEKPSEE BLARK FGFEEDYYKGT I SWW-- -QEMK PR IWSLFDEPYSSNAAKTIGVUSVFF ICI SILSFCLKTHP-DMR MTYRQHRDAEEA LDSFGGAPLDNSADDADADGPG---DSGDGEDELEMT- - - - - KRLALSD-SPD-GRPGGFW- - - - - RRWQPR IWALF BDPY SSR

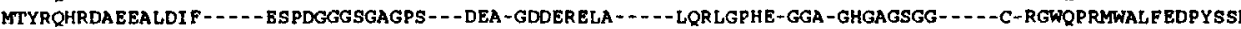

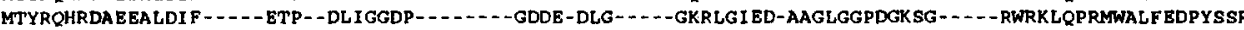
MTYRQHRDA EEALDSFEAPDSSANANANAGGAHDAGLDDEAGAGGGGLDGAGGELKRLCFQDAGGGAGGLPGGAGGAGGTWWRRWQPRVWALF EDPY SSR MTYROHRDAEEALDSFEAPDSSGNANANAGGAHDAGLDDEAGAGGGG LDGAGGELKR LCFODAGGGAGGPAGGPGGAGGTWWRRWOPRVWALFEDPY SSR MTYROHRDAEEALOSFEAPDS SGNANANAGGAHDAGLDDEAGAGGGGLDGAGGELKRLCFODAGGGAGGPAGGPGGAGGTWWRRWOPRVWALFEDPYSSR MTYRQHRDAEEALDSFEAPDSSANANANAGGAHDAGLDDEAGAGGGGLDGAGGELKRLCFQDAGGGAGDL PGAR -AAGATWWRWQPRVWALF EOPY SSR

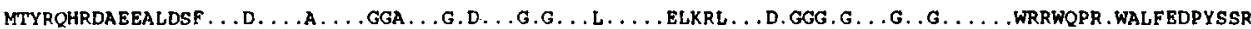
81 32

VP IVRNITVK--TANGSNGWFLDKTOTNAH IAFFY I - ECVCNAWFTFEILVRFISSPNKWEFIKSSVNI IDYIATLSFY IDLVLORFASHLENADILEFF YARYVAFASLFF I LVS I TTFCLETH ER FNPIVNKT - - EI ENVRNGTQVRYYR -EAETEAFLTY I EGVCVVWFTFEFLMRVVFCPNKVEFI KNSLNI IDFV AARVVAFASLFFILUS ITTFCLETHEA FNIDRNVT - - EILRVINITSVHFRR-EVETEP ILTY I EGVCVLWFTLEFLVR IVCCPDTLDFVKNLLNI IDFV AARF LAFA SLF I IUSI TTFCLETH EAFNIVKNKT - - EPV INGTSAV LQY - - EI ETDPALTYVEGVCVVWFTFEFLVR IVF SPNKLEF I KNL LNI IDFV AARYVAFA SLFF I I I ITTTCLETHEGF I I I SNKTVTRQA SP I PGA PPENI TNVEVETEPFLTYVEGVCVVWFT FE FLMRVTFCPDKVEF LKSSLNI IDCV AARYVAFASLFF I I I ITTFCLETHEGF I I I SNKTVTOASP I PGA PPENI ITVVEVTEPF LTYVEGVCVVWFTFEFLMRVTFCPDKVEFLKSSLNI IDCV AARYVAFASLFFILISITTTFCLEMIEGF IHISNKTVTOASP I PGAPPENI TNVEVETEPFLTYVEGVCVVWFTEEFLMRVTFCPDKVEFLKSSLNI IDCV AARYVAFASLFF I I SI TTFCLETHEGF I I I SNKTVTQASP I PGA PPEN I TNVEVETEPFLTYVEGVCVVWFTFEFLMRVTFCPDKVEFLKSSLNI IDCV

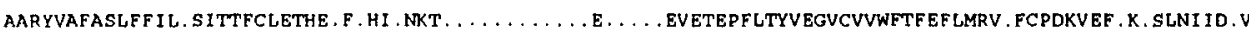
85

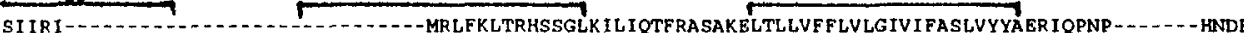
AI LPFYLEVGLSGLSSKAAKDVLGFLRVYRFVRILR IFKLTRHFVGLRVLGHTLRASTNEFLLLI I FLALGVLIFATMI YYAER IGAOPNDPSASEHTHE AILPFYLEVGLSGLSSKAARDVLGFLRVVRIVRI LR I F KLTRHFVGLRVLGHTLRASTNEF LLLI IF LALGVLIFATMI YYAER IGARPSDPRGNDHTUP A I LPFY LEVGLSGLS SKAARDV LGFLRVVR I VRI LR I F KLTRHFVGLRVLGHTLRASTNEF LLLII I LALGVLI IFATMI YYAER I GAR PSUPRGNDHTUF A I LPFYLEVGLSGLSSKAAKDV LGF LRVVRFVRI LR I FKLTRHFVGLRVLGHTLRASTNEFLLLI I F LA LGVL I FATMI YYAERVGAQPNDPSA SEHTQF
A I LPFYLEVGLSGLS SKAAKDVLGF LRVVRFVRI LR I FKLTRHFVGLRVLGHTLRASTNEF LLLI I F LA LGVL I FATMI YYAER I GADPDDI LGSNHTYF AI LPFYLEVGLSGLSSKAAKDVLGFLRVVRFVRI LR I FKLTRHFVGLRVLGHTLRA STNEFLLL I I FLALGVL I FATMI YYAER IGADPDDI LGSNHTY AI LPFY L EVGLSGLSSKAAKDV LGFLRVVRFVRI LR I FKLTRHFVGLRVLGHTLRASTNEFLLL I I F LALGVL I FATMI YYA ER I GADPDDI LGSNHTYF AILPFYLEVGLSGLSSKAAKDVLGELRVVRFVRI LR I FKLTRHFVGLRVLGHTLRASTNEFLLL, I I FLALGVLI FATMI YYAER I GADPDDI LGSNHTYF AILPFYLEVGLSGLSSKAAKDVLGFLRVVREVRILR I FKLTRHFVGLRVLGHTLRASTNEFLLLII FLALGVLIFATMIYYAER IGA . P.D. . GS . HT . F

\section{6}

NS I PLGLWWALVTMTTVGYGDMAPKTY IGMFVGALCALAGVLTIALPVPVIVSNFAMYYSHTQARAKLPKKRRRVLP-VEQPRQPRL - -PGAPG - - - - KNI P IGFWWAVVTMTTLGYGDMY POTWSGMLVGA LCALAGVLTIAMPVPV IVNNFGMYYSLAMAKOKLPKKKKKH I PRPPOLGSPNYCKSVVNS-.--- P KNIP IGFWWAVVTMTTLGYGOMYPKTWSGMLYGA LCALAGVLTIAMPYPV IVNNFGMYYSLAMAKOKLPKKRKKHYPRPAOLESPMYCKS EETS-...KNI I IGFWWAVVTMTTLGYGDMYPOTWSGMLVGA LCALAGVLT TAMPVPVIVNWEGMYYSLAMAKQKLPRKRKKH I PPAPLASSPTFCKTELNM - - - - -

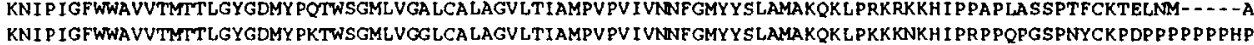
KNI P IGFWWAVVTMTTLGYGDMY PKTWSGMLVGGLCALAGVLTIAMPVPVIVNNFGMYYSLAMAKQKLPKKKNKH I PR PPQFGSPNYCKPDPPP PPPPHP KNIP IGFWWAVUTMTTLGTGOMYPKTWSGMLVGA LCALAGVLTI MPVPV IVNNEGMYTSLAMAKOKLPKKKNKH IPRPPOPGSPNYCKPDPPPPPPPHP KNI P IG FWWAVVTMTTLGYGDMY PKTWSGMLVGGLCALAGVLTIAMPVPVIVNNFGMYYSLAMAKQKLPKKKNKH I PRPPOPGSPNYCKPDPPPPPPPHP KNI PIGFWWAVVTMTTLGYGDMY PKTWSGMLVGA LCALAGVLTIAMPVPV IVNING GYY SLAMAKQKL PKKK , KHI PRPPQPGSPNYCKP . . . . . . . P

VSGCGTPGSG PHSGPMGSGGT - - $\ldots$ GPRRMNNKTKD - $-1,1$ HHSTQ- - SDTCP LAQEEILEI - . - . - - NRADSKLNG RDSTC-SDTSPPAREEGMIE- .

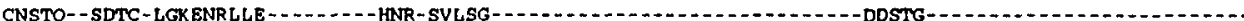

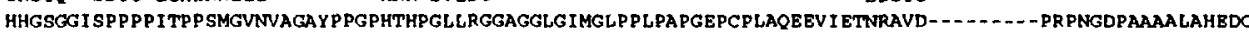
HHGSGG I $P$ P PP ITP PSMGVTVAGAY PPGPHTHPGLLRGGAGGLG I MGL P PL PA PGEPCPLAQE EV I ETNRAGNDLGVLEEGDPRPNGDPAAAALAHEDC HHGSGG I S PPPP I TPPSMGVTVAGA Y PPGPHTHPGLLRGGAGGLG I MGLPP LPA PGEPCPLAQEEV I ETWRAGE - . . . . . . HHGSGGI SPPPP ITPP SMGVNVAGAYPPGPHTHPGLLRGGAGGLG IMGLPPLPA PGEPCPLAQEEV I ETNRAGE - ............ AGARTGGVGRSGC

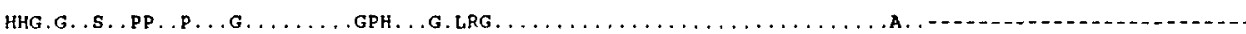
20 . PATE PAIDQPAMSPEDKSP ITPGSRGRYSRDRACFLVTDYAPSPDGSIRK - $\ldots \ldots \ldots$. PAI DQPAMSPEDKSP ITPGSRGR YSRDRACF LVTDYA PSPDGSIRKATGAPPLPPHAGVSQAPPASCPTST PTQQPGYPP SGRAPSPPQATPEAPAI FDV PAID KVAGLEGMOGOGFLGSGRVGWEA -TADRKDKWLEGWTPGTKSHRNR $-\ldots \ldots \ldots \ldots$

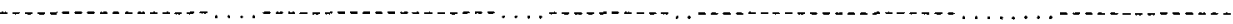
. (1) WLPPFHRSHQP PGKHQRGGRHPGVSPSPQQRACVGEPPSASHPQSLTLCISVPSSCHRLRPRETLGFPLSLPPRLATGNGGRECPRDPGLPFPSRHSSPA - EHGF EH
297

284
320 
$2 \times$ saline-sodium citrate (SSC), $1 \%$ SDS or $0.2 \times$ SSC, $0.1 \%$ SDS at $65^{\circ} \mathrm{C}$ and exposed onto Kodak XAR-5 film at $-70^{\circ} \mathrm{C}$ with an intensifying screen.

cDNA subtraction. Three micrograms of polyA ${ }^{+}$RNA isolated from normal mouse cerebellum were transcribed into ${ }^{32} \mathrm{P}$-dCTP-labeled cDNA (Riboclone cDNA synthesis kit from Promega, Madison, WI). This cDNA was subjected to two rounds of subtractive hybridization. It was hybridized for $40 \mathrm{hr}$ in a small volume at $65^{\circ} \mathrm{C}$ in a $1: 10$ ratio with photobiotinylated L-cell mRNA (Sive and St. John, 1988). Photobiotinylation was performed with photoprobe biotin according to manufacturer's instructions (Vector Laboratories, Burlingame, CA). The cDNA/mRNA hybrids were removed by the addition of streptavidin and organic extraction, and the remaining RNA was hydrolyzed. Approximately $40 \%$ of the cDNA remained after the first round of subtraction. The subtraction was repeated using biotinylated mRNA from adult $p c d / p c d$ mice. Less than $10 \%$ of the starting cDNA was recovered. Second-strand cDNA synthesis was performed. EcoRI adaptors were ligated to double-stranded cDNA, phosphorylated, and size selected on a CL4B (Sigma) column (Ausubel et al., 1987). The cDNAs had an average size of less than 500 base pairs (bp). cDNAs were ligated to $\lambda$ GT10 (Huynh et al., 1985) and packaged in vitro following manufacturer's instructions (Gigapack II Gold packaging extract from Stratagene, La Jolla, CA). A total of $3.4 \times 10^{4}$ plaques were obtained. cDNA insert sizes were determined by polymerase chain reaction (PCR) analysis. Approximately $20 \%$ of the resulting plaques had insert sizes $>100$ bp.

cDNA insert size determination. Phage were eluted from isolated plaques in $100 \mu \mathrm{l}$ of suspension medium (SM) for several hours at room temperature. Two microliters of the eluant were used in a $100 \mu \mathrm{l} \mathrm{PCR}$ reaction with oligo primers that flanked the $\lambda G T 10$ cloning site. The sizes of the PCR products were determined by gel electrophoresis on agarose gels.

Normal cDNA libraries. Total RNA was subjected to two rounds of oligo-dT (Bethesda Research Laboratories, Gaithersburg, MD) selection. Double-stranded cDNA was prepared using an oligo-dT NotI primer-adaptor (Promega) and the Riboclone cDNA synthesis kit (Promega) according to manufacturer's instructions. Hemiphosphorylated EcoRI adaptors (Promega) were ligated onto the cDNA. The cDNA was digested with NotI, kinased, and size selected over a CL4B (Sigma) column (Ausubel et al., 1987). The cDNA was ligated to the dephosphorylated EcoRI/NotI-digested arms of the $\lambda$ gt 11 SfiI-NotI vector and packaged in vitro (Gigapack II Gold packaging extract from Stratagene, La Jolla, CA); $1.5 \times 10^{6}$ individual clones were obtained. The average insert size was 1.5 kilobases (kb), and $9 \%$ contained no inserts. The library was amplified and stored at $4^{\circ} \mathrm{C}$.

A second cDNA library was made as above but without NotI digestion. It was ligated into the EcoRI site of $\lambda \mathrm{GT} 10$ and packaged in vitro (Gigapack II Gold packaging extract from Stratagene, La Jolla, CA).

A 5' cDNA library was made by priming mRNA with the oligo CGCCAGCTGGCTCCTCCAAGCCC to make double-stranded cDNA using the Riboclone cDNA synthesis kit (Promega). EcoRI adaptors (Promega) were attached to the ends, and the cDNA was size selected on a CL4B (Sigma) column (Ausubel et al., 1987). A fraction of the cDNA was cloned into dephosphorylated EcoRI-digested Bluescript $\mathrm{KS}(+)$ vector (Stratagene, La Jolla, CA). The DNA was transformed into frozen competent XL1-Blue cells (Stratagene, La Jolla, CA).

Cosmid library. The genomic library was a $\mathrm{C} 57 \mathrm{~B} / 6$ genomic library (Stratagene, La Jolla, CA) in the pWE 15 vector. Screening was done according to manufacturer's instructions.

In situ hybridization of tissue slices. Dissected brains from normal adult mice were embedded in OCT (Miles, Inc., Elkhart, IN) and frozen at $-70^{\circ} \mathrm{C}$. Ten-micron serial sagittal sections were cut on a cryostat and mounted on subbed slides. They were fixed in $4 \%$ paraformaldehyde, $0.1 \mathrm{~m}$ phosphate buffer ( $\mathrm{pH} \mathrm{7.4)}$ for $30 \mathrm{~min}$ at room temperature, washed in PBS twice for 10 min each, dehydrated through an ethanol gradient, and stored at $-20^{\circ} \mathrm{C}$.

For the P6, P8, P10, and P12 slides, sections were prepared as previously described (Kuhar et al., 1993).

Riboprobe synthesis using digoxigenin-11-UTP (Boehringer Mannheim) and in situ hybridization were as previously described (Kuhar et al., 1993).

\section{A}

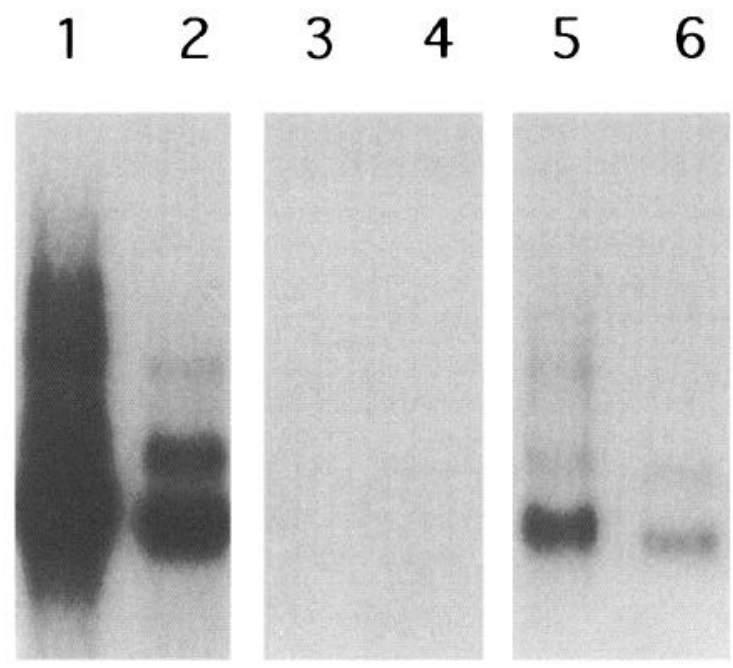

B
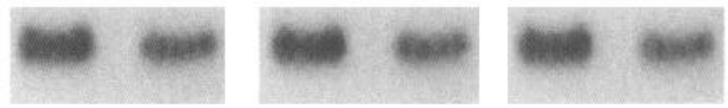

Figure 4. Northern blot analysis of the $3^{\prime}$ ends of the Kv3.3 cDNAs. Lanes 1,3 , and 5 contain $2 \mu \mathrm{g}$ of polyA + RNA from cerebella of normal adult mice. Lanes 2,4 , and 6 contain $2 \mu \mathrm{g}$ of polyA ${ }^{+}$RNA from cerebella of $p c d / p c d$ mice. In $A$, lanes $I$ and 2 were probed with the $940 \mathrm{bp}(8118)$ fragment, lanes 3 and 4 were probed with the PCR fragment generated from the $3^{\prime}$ end of the Ghanshani message using the primers GAGGCTGGGGCCAGGACT and CACCTGGGTTTCTGAATC, and lanes 5 and 6 were probed with the PCR fragment generated from the 3 ' end of our B3.1 clone using the primers GACCCCCGTCCCAATGGA and TGGGCTCTTGTCTTCTG. In $B$, the same Northern strips that were used in $A$ were probed with an actin control.

Cerebellar cell culture. Cultures were prepared from late embryonic (E18) mice using methods previously used to dissociate cerebellar cells (Hatten and Sidman, 1978; Trenkner and Sidman, 1981; Hatten, 1985; Baird et al., 1992). Timed-pregnant female mice were deeply anesthetized with ketamine/xylazine, and embryos were removed. Brains were dissected from the embryos. Cerebella were obtained by dissection and stripped of meninges under chilled calcium/magnesium-free phosphatebuffered saline (Tyrode's solution, PBS). Cerebella were immersed in calcium-free PBS containing trypsin (Worthington; 1\%) and DNase (Worthington; $1 \%$ ) for $3 \mathrm{~min}$ at $20^{\circ} \mathrm{C}$. Trypsin/DNA solution was replaced with Eagle's basal medium (BME) supplemented with $0.33 \%$ glucose containing DNase $(0.05 \%)$, and cerebella were dissociated by trituration in three Pasteur pipettes fire polished to progressively finer bores. The resulting cell suspension was pelleted with brief centrifugation and resuspended in serum-containing medium. Clumps of cells were removed by passing the suspension through a $33 \mu$ m nylon mesh (Tetco, Inc., Elmsford, NY) in a syringe-mounted filter holder. The cell concentration of the suspension was determined using a hemocytometer and adjusted to $8 \times 10^{5} \mathrm{cells} / \mathrm{ml} ; 0.25 \mathrm{ml}$ of the suspension was plated into each well of 16-well Lab-Tek chamber slides (Nunc) coated with poly-D-lysine hydrobromide (Sigma; MW $>300,000 ; 0.5 \mathrm{mg} / \mathrm{ml}$ ), for a plating density of $2 \times 10^{5}$ cells $/$ well $\left(4000\right.$ cells $\left./ \mathrm{mm}^{2}\right)$. Cultures were incubated at $35.5^{\circ} \mathrm{C}$ in $5 \% \mathrm{CO}_{2}$. Two hours after plating, cells had adhered sufficiently to replace the serum-containing medium with serum-free medium. Neuron survival is increased and glial proliferation is decreased in serum-free medium (Baptista, Blazeski, Hatten, and 
A

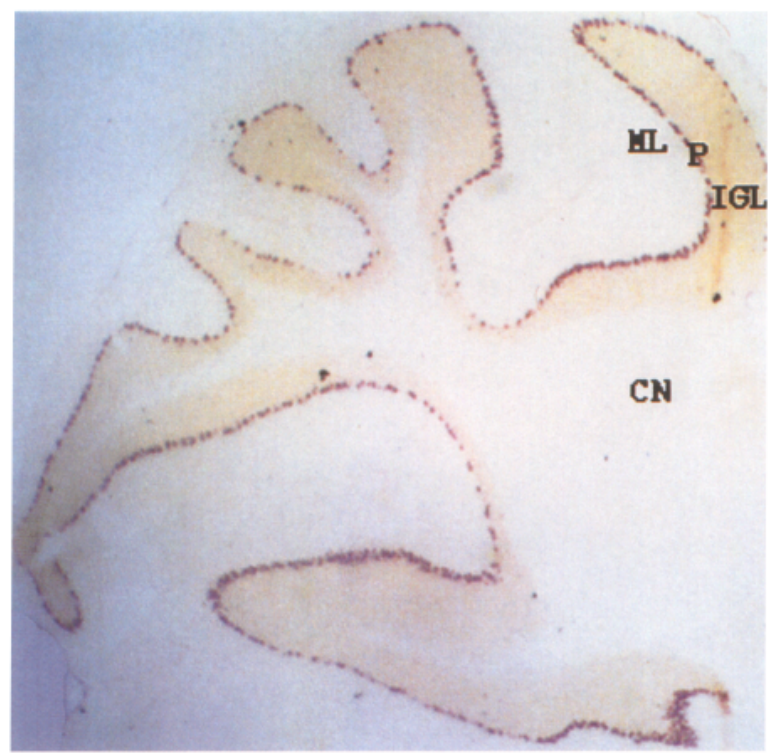

C

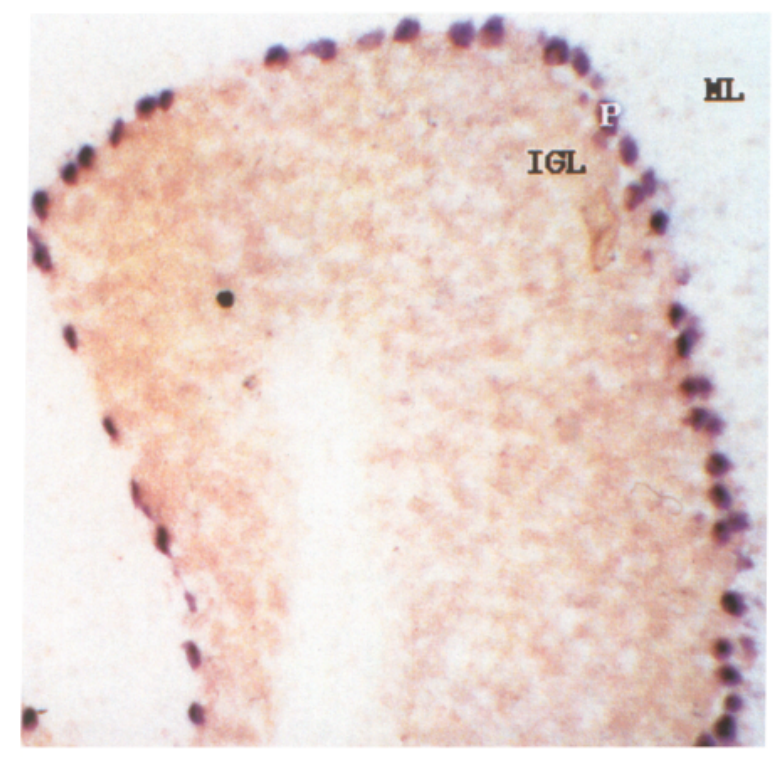

B

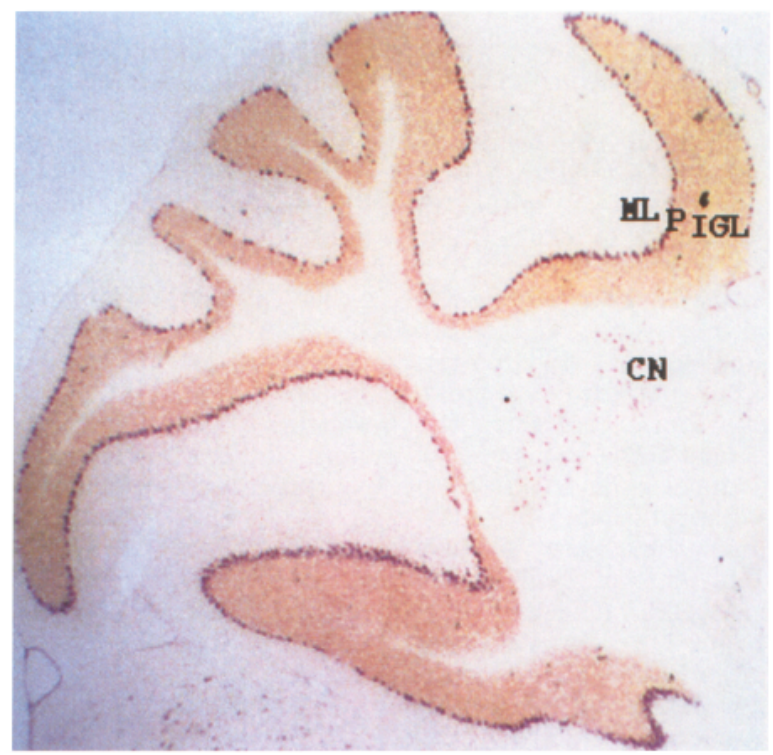

D

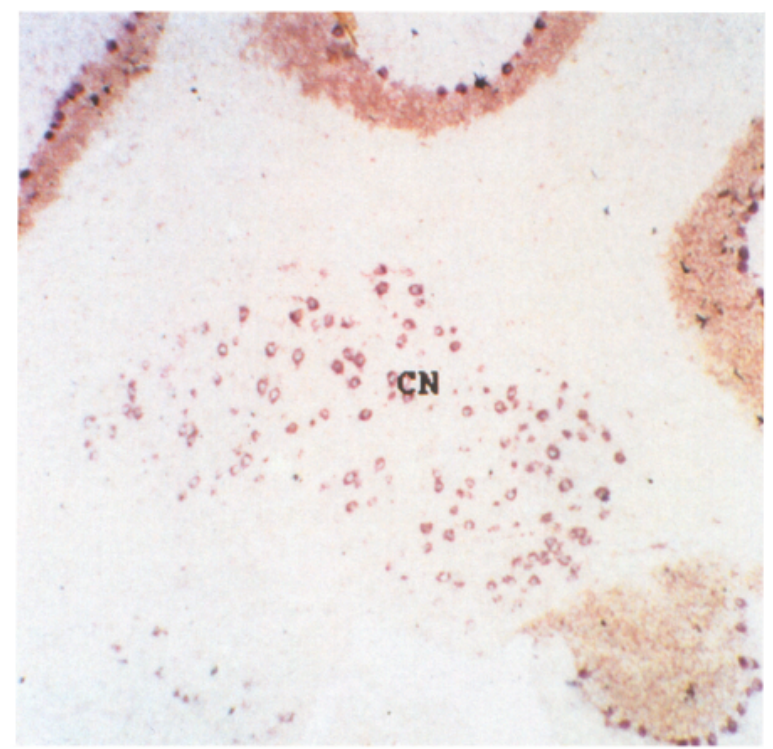

Figure 5. In situ hybridization analysis of adult mouse brain sections. $A$ shows hybridization with the antisense calbindin probe. $B-D$ show hybridization with the antisense 8118 probe. $I G L$, internal granule layer; $P$, Purkinje cell layer; $M L$, molecular layer; $C N$, deep cerebellar nuclei.

Mason, unpublished observations). Cultures were incubated 7, 14, and $21 \mathrm{~d}$ before fixation.

Serum-containing medium for cerebellar cell culture (Baird et al., 1992) consisted of Eagle's basal medium with Earle's salts (GIBCO) supplemented with $10 \%$ horse serum (GIBCO), 2 mm L-glutamine, glucose (final concentration $32 \mathrm{~mm}$ ), and penicillin/streptomycin (GIBCO; $20 \mathrm{U} / \mathrm{ml}$ each).

Serum-free medium suitable for long-term culture of Purkinje cells (Baptista, Blazeski, Hatten, and Mason, unpublished observations) was used, consisting of Eagle's basal medium with Earle's salts (GIBCO) supplemented with insulin $(10 \mu \mathrm{g} / \mathrm{ml})$, transferrin (Sigma; $100 \mu \mathrm{g} / \mathrm{ml})$, sodium selenite (Sigma; $30 \mathrm{~nm}$ ) putrescine (Sigma; $100 \mu \mathrm{M}$ ), progesterone (Sigma; $20 \mathrm{~nm}$ ), $2 \mathrm{~mm}$ L-glutamine, glucose (final concentration of 32 $\mathrm{mM}$ ), and penicillin/streptomycin (GIBCO; $20 \mathrm{U} / \mathrm{ml}$ each).

In situ hybridization of cultured cells. Cultures to be hybridized were fixed in 4\% paraformaldehyde in Sorensen's phosphate buffer for 30 min at $20^{\circ} \mathrm{C}$. Cultures were washed three times in sterile PBS treated with $0.1 \%$ diethyl pyrocarbonate (Sigma) and stored overnight at $4^{\circ} \mathrm{C}$. PBS was then replaced with $70 \%$ ethanol (Groslin and Banker, 1991) to preserve RNA and reduce microbial growth until the day of hybridization, when they were returned to PBS. Cultures were washed three times in PBS immediately before prehybridization treatment. The digoxigenin method for nonisotopic in situ hybridization to sections $\mathrm{Cu}-$ har et al., 1993; present results) was used for cultured cells, with the following minor modifications. Tops and sides of the Lab-Tek chamber slides were removed, leaving the gasket, which forms a well to contain solutions for hybridization. Proteinase $\mathrm{K}$ treatment was reduced to 5 min to minimize the removal of cells from the slides. Cultures were not air dried preceding application of probe to prevent shrinkage and associated damage to cell cultures. After dehydrating in an ethanol series to $100 \%$ ethanol, cultures were returned to $2 \times$ SSC via the same ethanol series; $2 \times$ SSC was removed, and $15 \mu$ of probe was applied per well 
(a)

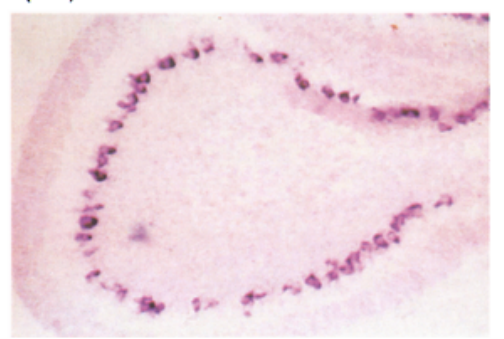

(d)

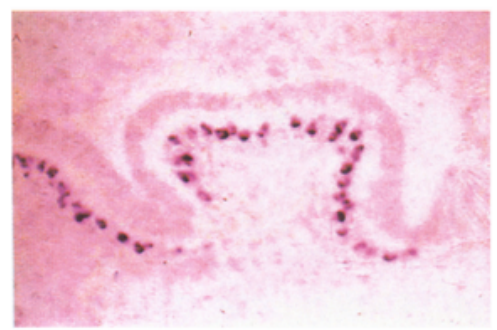

(g)

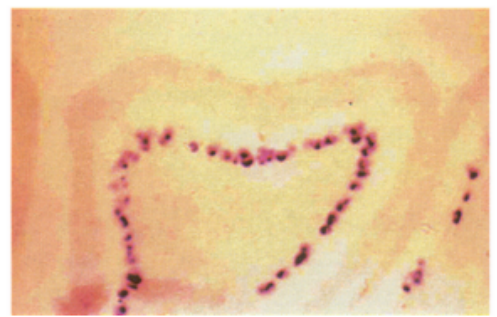

( j )

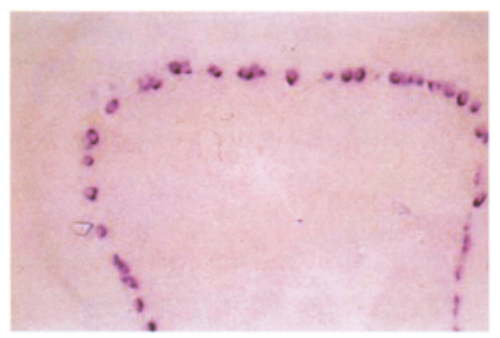

(b)

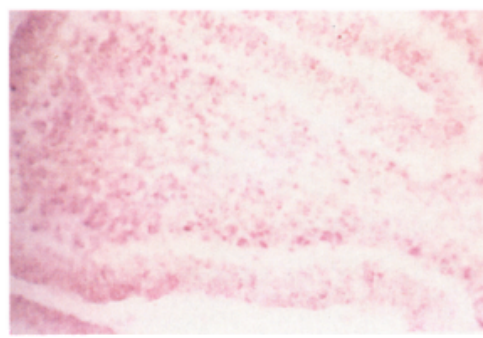

(e)

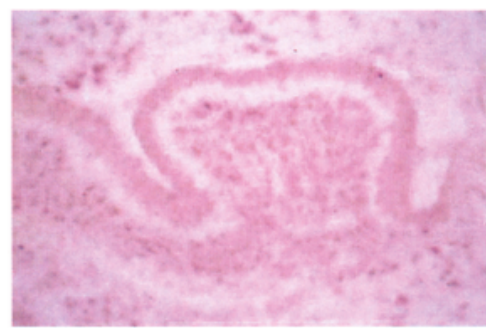

(h)

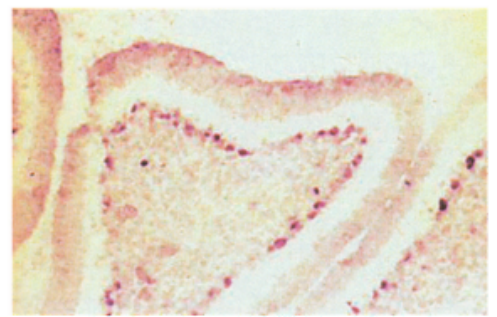

(k)

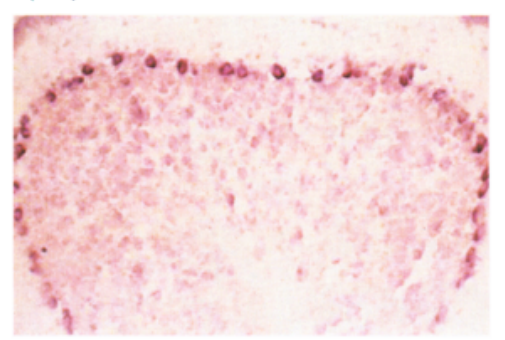

(c)

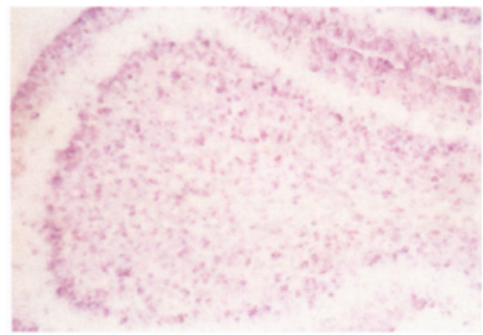

(f)

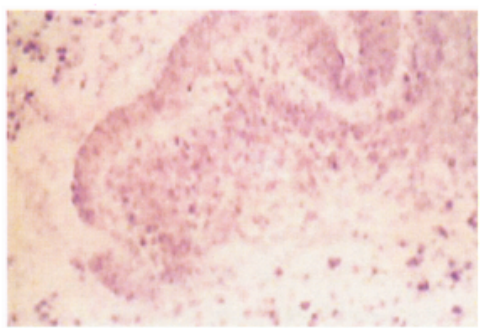

(i)

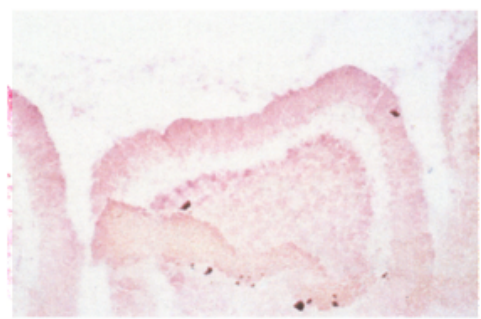

(1)

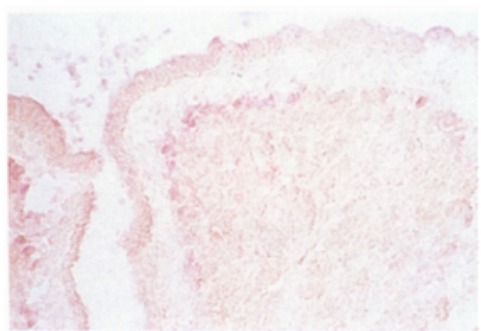

Figure 6. In vivo time course of $\mathrm{Kv} 3.3 \mathrm{~b}$ expression in $\mathrm{P} 6, \mathrm{P} 8, \mathrm{P} 10$, and $\mathrm{P} 12$ mouse cerebellar sections. $a-c$ are $\mathrm{P} 6$ cerebellar sections, $d-f$ are $\mathrm{P} 8$ cerebellar sections, $g-i$ are P10 cerebellar sections, and $j-l$ are P1 2 cerebellar sections. $a, d, g$, and $j$ are stained with a calbindin antisense probe to identify the Purkinje cells. $b, e, h$, and $k$ are stained with the 8118 antisense probe to identify Kv3.3b-positive cells. $c, f, i, a$ and $l$ are control slides stained with the 8118 sense probe. Expression of the Kv3.3b gene is visible by P10 in a subset of the Purkinje cells $(h)$. By P12, virtually all of the Purkinje cells are expressing the potassium channel $(k)$.

at a final dilution of 1:400 in hybridization buffer. No coverslips were applied. Cultures were hybridized $12-16 \mathrm{hr}$ at $55^{\circ} \mathrm{C}$ in a humid, sealed container. The remainder of the procedure was similar to that described for sections, except that cultures were immunolabeled before the alkaline phosphatase reaction to label hybridization.

Combining in situ hybridization with immunolabeling in a single culture. Antiserum raised in rabbit against calbindin- $\mathrm{D}_{28 \mathrm{~K}}(1: 1000$; gift of Dr. Sylvia Christakos) was applied together with alkaline phosphataseconjugated anti-digoxigenin antibody raised in sheep (Boehringer Mannheim; 1:500); cultures were incubated in a humid chamber at $4^{\circ} \mathrm{C}$ for 16-22 hr. Cultures were then washed three times, 10 min each wash, in Tris-buffered saline (TBS) with $0.1 \mathrm{M}$ Tris, $150 \mathrm{~mm} \mathrm{NaCl}, \mathrm{pH} 7.5$.
Rhodamine-conjugated anti-rabbit secondary antibody was applied (1: 100 ) for $30 \mathrm{~min}$ at $20^{\circ} \mathrm{C}$ in a humid chamber. Cultures were washed three times, $10 \mathrm{~min}$ per wash, followed by a $10 \mathrm{~min}$ wash in alkaline phosphatase reaction buffer (TBS with $100 \mathrm{~mm} \mathrm{NaCl}, 50 \mathrm{~mm} \mathrm{MgCl}$, $\mathrm{pH}$ 9.5). Alkaline phosphate substrate solution $(0.33 \mathrm{mg} / \mathrm{ml}$ 4-nitro blue tetrazolium chloride (NBT); $0.165 \mathrm{mg} / \mathrm{ml}$ 5-bromo-4-chloro-2-indoylphosphate (BCIP); $0.24 \mathrm{mg} / \mathrm{ml}$ levamisole) was applied, and incubated in a humid chamber for $60 \mathrm{~min}$. The reaction was stopped by immersion in $10 \mathrm{~mm}$ Tris; $1 \mathrm{~mm}$ EDTA, pH 8.0. Gaskets forming wells were removed from chamber slides, and slides were dipped in distilled water. Slides were then coverslipped with Gelmount (Biomeda), an aqueous mountant. Cultures were photographed using a microscope equipped 
with a $25 \times$ phase objective. Fluorescence photomicrographs using rhodamine optics were taken to record calbindin- $D_{28 K}$ immunolabeling, and hybridization photographed using bright-field optics.

\section{Results}

\section{Preparation of Purkinje cell-enriched cDNA library}

To prepare a cDNA library enriched in genes expressed in Purkinje cells or whose expression was dependent upon the presence of functioning and viable Purkinje cells, we took advantage of the existence of Purkinje cell degeneration $(p c d)$ mice. Adult pcd mice have lost greater than $99 \%$ of their Purkinje cells without a corresponding loss of other cerebellar cell types (Mullen et al., 1976). Thus, we employed a two-step subtractive hybridization procedure to generate a cDNA library enriched for Purkinje cell-specific cDNA clones. The first step involved hybridization against a fivefold excess of mouse L-ccll mRNA to eliminate abundant housekeeping genes. The second round of subtraction was against a fivefold excess of $p c d / p c d$ mouse cerebellar mRNA. This second round of hybridization/subtraction eliminated brain cDNAs that were not Purkinje cell specific or whose expression was Purkinje cell independent. Through this double-step hybridization/subtraction, we hoped to enrich for Purkinje cell cDNAs without requiring that they encode very abundant mRNAs or that their expression be absolutely restricted to Purkinje cells.

Northern blot analysis of 10 randomly picked cDNAs from the resulting subtracted cDNA library revealed five clones that were expressed equally in normal cerebellum, $p c d$ cerebellum, and L-cells: one cDNA that was expressed at equal levels in normal and $p c d$ cerebella but not in L-cells, three cDNAs that were expressed at undetectable levels by Northern analysis, and one clone ( $\mathrm{pcd} 8$ ) that was cxpressed at elevated levels in normal versus $p c d$ cerebella and was undetectable in L-cells (data not shown). Although we do not yet have definitive data on the three clones expressed at undetectable levels, we believe that they encode rare Purkinje cell-specific messages whose expression can best be analyzed by in situ hybridization. From this limited sample of the cDNA library, it appears that the subtraction procedure effectively enriched for Purkinje cell cDNAs (they represent $10-40 \%$ of the population).

\section{Tissue-specific expression}

The original 258 bp cDNA fragment (pcd8) isolated in this screen was sequenced and no significant homology was found to any sequences in the GenBank or EMBL databases. This fragment was then used to isolate a 940 bp clone from an oligo$\mathrm{dT}$-primed normal adult cerebellar cDNA library. This new fragment (8118) was also not represented in the databases. This larger cDNA fragment was used to examine the expression of its cognate mRNA, both to confirm and extend the initial results obtained with the original 258 bp fragment (data not shown). As shown in Figure $1 A$, Northern blot analysis of mRNA isolated from normal adult cerebellum reveals a major transcript of $5.5 \mathrm{~kb}$, and less abundant transcripts of $6.5,9.0$, and $12 \mathrm{~kb}$. Comparison with the transcripts evident in mRNA prcpared from adult $p c d$ cerebellum demonstrates that the $5.5 \mathrm{~kb}$ transcript is significantly depressed relative to the minor bands in the mutant mRNA. None of these transcripts are present in mRNA prepared from mouse L-cells. These results indicated that the $8118 \mathrm{cDNA}$ encoded a transcript whose expression may be restricted to Purkinje cells, and that the 8118 gene is either alternatively spliced or a member of a gene family.
To determine whether the 8118 transcript is specifically expressed in brain, Northern blot analysis was used to assay its abundance in several other tissues in adult mouse. As shown in Figure $1 B$, mRNAs hybridizing to the 8118 probe are expressed at very high levels in adult cerebellum and at lower levels in forebrain, but are not present at significant levels in mRNA isolated from several other tissues.

\section{Developmental regulation}

Since our particular interest is to isolate cDNA clones that mark the final stages of Purkinje cell differentiation, expression of the $8118 \mathrm{mRNA}$ during development was analyzed by Northern blot (Fig. 1C). No expression of the $8118 \mathrm{mRNA}$ was detected in cerebellar RNA isolated in the first postnatal day (P0). Low levels are evident in RNA prepared at P10, and these levels increase and become maximal in adult cerebellum. Thus, the expression of this clone is positively developmentally regulated with a time course that parallels the time course of the terminal differentiation of Purkinje cells.

\section{Identification of a novel potassium channel CDNA}

Since the 940 bp fragment did not contain an open reading frame, and was not homologous to sequences in the GenBank or EMBL databases (Pearson and Lipman, 1988), additional cDNAs were isolated to identify the proteins expressed from this gene. A $1.8 \mathrm{~kb}$ cDNA fragment (5-2) was isolated that upon sequencing was found to contain more 3 ' sequence but no additional 5' sequence. This new sequence was still not represented in the databases and, as expected, it also did not contain an open reading frame. To obtain $5^{\prime}$ sequence that would contain coding sequences, a cDNA library primed with a $24-$ mer approximately $400 \mathrm{bp}$ away from the $5^{\prime}$ end of the $940 \mathrm{bp}$ fragment was prepared. Using the $940 \mathrm{bp}$ fragment as a probe, we identified a clone (B3.1) containing a $1.6 \mathrm{~kb}$ insert. This $1.6 \mathrm{~kb}$ insert contained an open reading frame that upon sequencing was found to be a novel cDNA from the previously reported Kv3.3 Shaw type potassium channel gene (Pearson and Lipman, 1988; Ghanshani et al., 1992). Figure 2 shows the full cDNA sequence of this novel channel. Comparison of this sequence with the published Kv 3.3 sequence reveals that the first 1744 nucleotides of the KV3.3 DNA sequence are present in our clone. However, the sequence we have determined contains an additional 231 nucleotides at the $5^{\prime}$ end because we noticed an in-frame ATG initiation codon upstream from that reported for $\mathrm{Kv} 3.3$. In addition, after nucleotide 1744 of Kv3.3 the two sequences diverge completely. The remaining 3111 nucleotides of the transcript we have identified are not present in the predicted Kv3.3 mRNA and result in a deduced $\mathrm{K}^{*}$ channel protein that is different from the reported $\mathrm{Kv} 3.3$ protein for the C-terminal 110 amino acids. The amino acids coded for after the splice site and the additional amino acids at the $S^{\prime}$ end are highly homologous to the analogous region of KShIIID.l, a previously cloned rat Shaw channel (Vega-Saenz de Miera et al., 1992).

Since the KShIIIDI (Vega-Saenz de Miera et al., 1992) and Kv3.1 (Luneau et al., 1991) genes are alternatively spliced at precisely the position at which the cDNA we have isolated, now referred to as $\mathrm{Kv} 3.3 \mathrm{~b}$, and the predicted $\mathrm{Kv} 3.3 \mathrm{mRNA}$ diverge, it had been suggested that alternatively spliced Kv3.3 transcripts might also exist (Ghanshani et al., 1992). Therefore, to determine whether our cDNA encoded a new member of this family or an alternatively spliced version of the Kv3.3, we isolated and 
characterized genomic clones using the unique $\mathrm{Kv} 3.3 \mathrm{~b} \mathrm{3}$ ' sequences. A genomic map of the portion of a cosmid containing the Kv3.3 gene is shown in Figure 2. This genomic clone overlaps that previously isolated and identified as the Kv3.3 gene, proving that the $\mathrm{Kv} 3.3 \mathrm{~b}$ transcript is encoded by that locus. The structure of the Kv3.3b mRNA was mapped onto the genomic clones revealing two additional $3^{\prime}$ exons in the cDNA that together encode the carboxyl-terminal 110 amino acids and $\sim 3.0 \mathrm{~kb}$ of $3^{\prime}$ untranslated mRNA (Fig. 2). As shown in Figure 3 , the deduced protein from the $\mathrm{Kv} 3.3 \mathrm{~b}$ mRNA is very closely related to other Shaw type potassium channels. The Kv3.3b specific C-terminal region is unique, although significant homology between $\mathrm{Kv} 3.3 \mathrm{~b}$ and the rat KShIIID. 1 and $\mathrm{Kv} 4$ proteins is evident.

Taken together, our results and those reported by Ghanshani et al. (1992) suggest that the Kv3.3 gene is alternatively spliced, leading to $\mathrm{K}^{+}$channels with different $\mathrm{C}$-terminal domains. Since this has important implications for both the function and the regulation of expression of this gene, and because the 3 ' terminus of the $\mathrm{K} v 3.3 \mathrm{mRNA}$ was deduced from the genomic clone rather than an expressed cDNA, we sought to determine whether the predicted Kv3.3 mRNA was expressed. Thus, unique $3^{\prime}$ probes were prepared from the $\mathrm{Kv} 3.3$ and $\mathrm{Kv} 3.3 \mathrm{~b}$ sequences and hybridized to Northern blots containing adult cerebellar mRNA from adult normal and $p c d$ mice. As shown in Figure 4, the $\mathrm{K} v 3.3 \mathrm{~b}$-specific probe hybridized to the same transcripts seen using the larger Kv3.3b-specific $8118 \mathrm{cDNA}$. No transcripts hybridizing to the Kv3.3-specific 3 ' probe are evident even though the specific activity and size of this probe are equivalent to the Kv3.3b-specific probe. In fact, both probes detect single bands on genomic Southern blots, proving that the Kv3.3-specific probe should detect an mRNA if it were expressed (data not shown). At extremely long exposures, the Kv3.3-specific probe does detect very faintly the upper two bands on Northerns. We believe these faint signals come from RNAs that are not yet fully processed. From these data, we conclude that the previously reported $\mathrm{Kv} 3.3$ deduced mRNA is not expressed in cerebellum, although it remains possible that the $\mathrm{Kv} 3.3$ gene is alternatively spliced in other ways to generate transcripts containing as yet undetected 3 ' sequences.

\section{Cell-specific expression}

The pattern of expression of the Kv3.3b mRNA as assayed by Northern blot analysis demonstrated very high levels of expression in cerebellar cortex, and suggested that this gene might be specifically expressed in Purkinje cells. To determine whether this is the case, the 8118 cDNA was used to localize the expression of the Kv3.3b transcripts by in situ hybridization to adult mouse cerebellar sections. As shown in Figure 5, the Kv3.3b transcript is expressed at high levels in Purkinje cells (Fig. 5B$D)$. Direct comparison with the expression of calbindin mRNA (Fig. 5A), whose expression is known to be restricted to Purkinje cells, suggests that this mRNA is also restricted to Purkinje cells in the cerebellar cortex, but that it is also present in the deep cerebellar nuclei (Fig. 5D).

\section{Time course of expression in vivo and in primary cell culture}

To define more precisely the time of expression of the $\mathrm{Kv} 3.3 \mathrm{~b}$ transcript in cerebellar Purkinje cells, we examined its expression by in situ hybridization to a series of slides prepared at different ages. As demonstrated in Figure 6, expression of the
Kv3.3b mRNA begins between P8 and P10, and it is present in virtually all of the Purkinje cells by P12. Inspection of the data obtaincd from P10 (Fig. $6 g-i$ ) clearly indicates that the expression of this mRNA is not temporally synchronized in all Purkinje cells in a given folium. Thus, adjacent sagittal sections hybridized to calbindin versus Kv3.3b probes demonstrates that at P10 only some of the Purkinje cells are positive for expression of this $\mathrm{K}^{+}$channel. This suggests that the epigenetic mechanisms controlling the final stages of Purkinje cell differentiation may be triggered by interactions that impinge upon single Purkinje cells. Since previous studies have demonstrated the regulation of $\mathrm{K}^{+}$channel gene expression in hippocampus as a result of seizure (Tsaur et al., 1992), it is possible that this heterogeneity in the onset of Kv3.3b mRNA in Purkinje cells is related to developmental variations in the acquisition of mature Purkinje cell synapses with cerebellar granule cells during the second postnatal week. Alternatively, the biochemical heterogeneity of Purkinje cells (Hawkes et al., 1985; Ingram et al., 1985; Koh et al., 1989; Stainier and Gilbert, 1989; Brochu et al., 1990; Pioro and Cuello, 1990; Sotelo and Wassef, 1991) may in some way influence the precise temporal pattern of expression of this ion channel.

To provide an avenue for delineation of interactions regulating Kv3.3b expression and its subsequent contribution to mature Purkinje cell function, we were interested in determining whether the cell type specificity and developmental regulation of this gene are maintained in dissociated primary cultures of mouse cerebellum. To examine this question, cells were isolated from late embryonic mice (E18) as previously described (Hatten and Sidman, 1978; Trenkner and Sidman, 1981; Hatten, 1985; Baird et al., 1992). Mixed populations of cerebellar cells were then cultured for various periods, and analyzed using double staining by immunocytochemistry for calbindin to identify Purkinje cells and in situ hybridization for Kv3.3b mRNA to determine the time course of its expression. Since Purkinje cells become postmitotic at approximately E12 in vivo (Uzman, 1960; Miale and Sidman, 1961) and can be identified by calbindin staining shortly thereafter (Shamley et al., 1992), all cultures contained readily identifiable Purkinje neurons (Fig. $7 b, e, h, k$ ). Expression of the $\mathrm{Kv} 3.3 \mathrm{~b} \mathrm{mRNA}$ in culture follows its in vivo time course: it is not present in E18 Purkinje cells cultured for 1 weck, but it is cxpressed in virtually all of the calbindinpositive cells after 2 and 3 weeks in culture (Fig. $7 c, f, i, l)$. These results indicate that the timing of expression of this gene is quite faithfully maintained in primary cerebellar cell culture. Inspection of the phase-contrast and calbindin-stained cultures further reveals clearly identifiable Purkinje cell neurites after 1 week in culture in cells that do not express this $\mathrm{K}^{+}$channel, suggesting that its expression is not simply dependent on neurite extension, but correlates with subsequent morphologic maturation of Purkinje cells that has been previously documented in these cultures (Cohen-Cory et al., 1991; Baptista, Blazeski, Hatten, and Mason, unpublished observations).

\section{Discussion}

To elucidate the role of epigenetic molecular mechanisms in Purkinje cell differentiation, we sought to isolate markers for the later stages of Purkinje cell development by employing a two-step hybridization/subtraction technique that yielded a cDNA library enriched in Purkinje cell clones. Our approach led to the identification of a developmentally regulated novel 
(a)

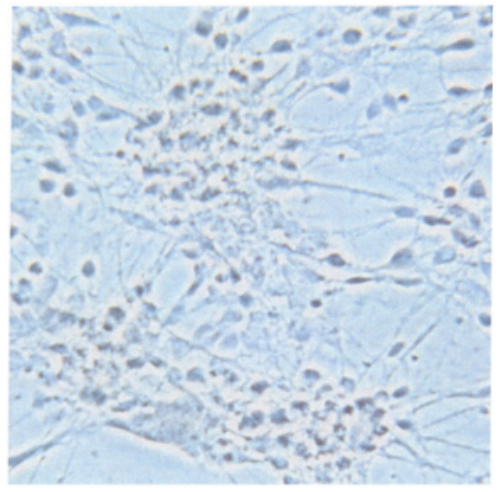

(d)

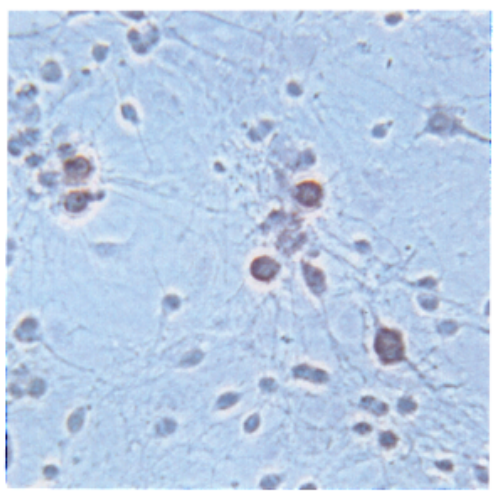

(g)

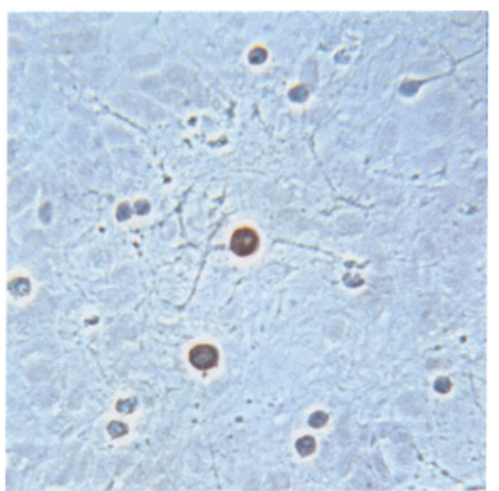

(j)

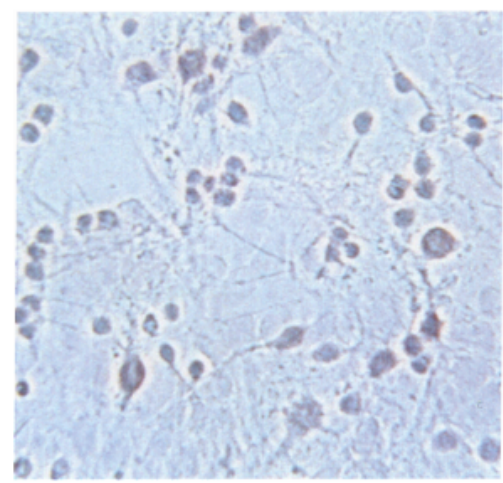

(b)

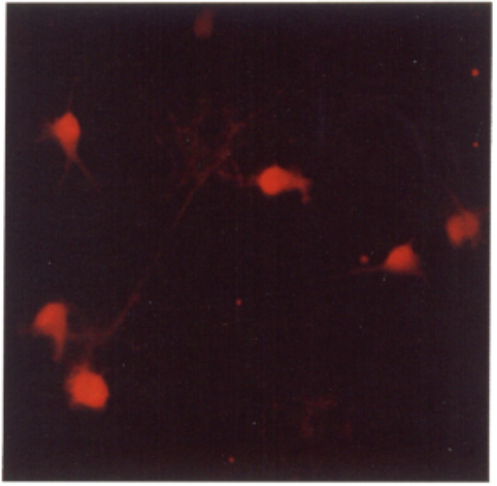

(e)

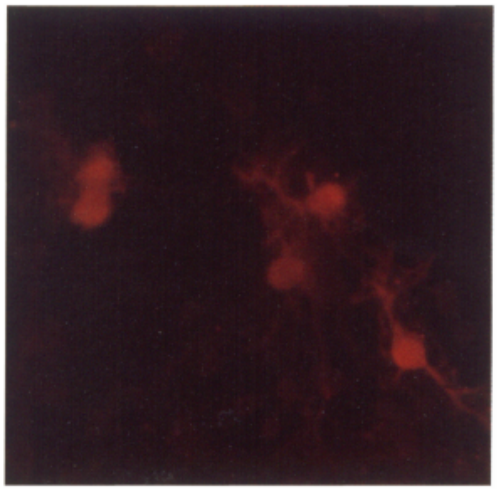

(h)

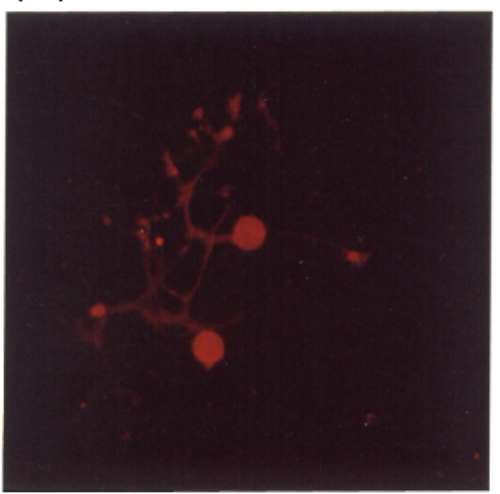

(k)

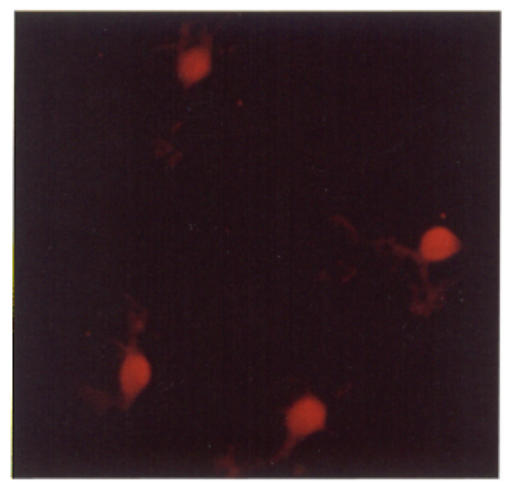

(c)

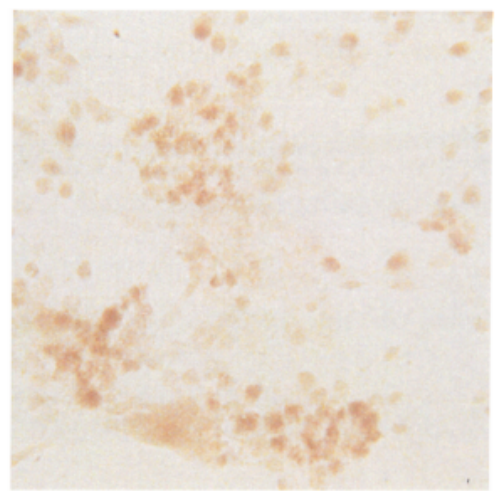

(f)

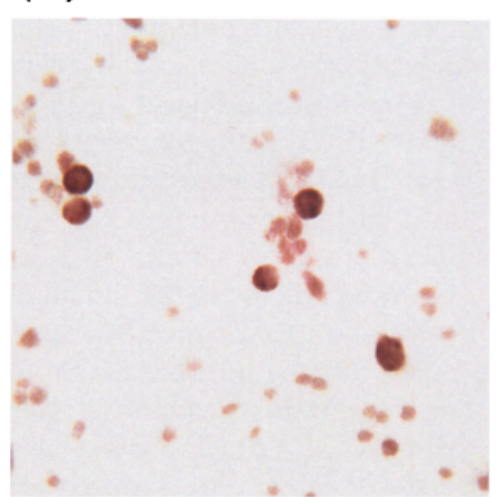

(i)

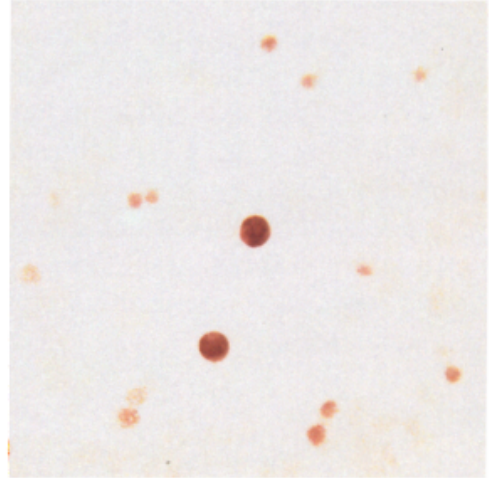

(1)

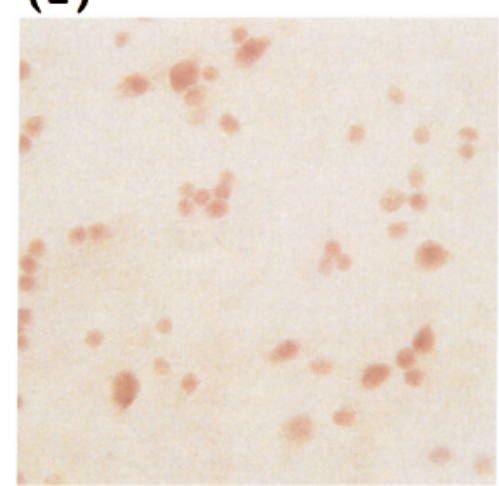

Figure 7. Specific expression of the Kv3.3b gene in Purkinje cells from E18 mouse embryos after $14 \mathrm{~d}$ in vitro, combining nonisotopic in situ hybridization with immunolabeling for calbindin- $\mathrm{D}_{28 \mathrm{~K}}$, a Purkinje cell marker. $a-c$ are taken after $7 \mathrm{~d}$ in vitro. Little or no potassium channel expression is detected in dissociated cerebellar cells using the 8118 antisense probe $(c)$ although many cells with neuronal and non-neuronal morphology are visible in phase optics $(a)$. Purkinje cells are identified by immunolabeling for calbindin- $\mathrm{D}_{28 \mathrm{~K}}(b)$ and have not attained a mature 
Shaw type potassium channcl cDNA that is expressed in Purkinje cells and deep nuclei in the cerebellum.

The Shaw type potassium channels are a subfamily of delayed-rectifier potassium channels believed to be important in setting the resting membrane potential (Salkoff et al., 1992) and for repolarization of the membrane potential during an action potential and thus are important modulators of action potential duration (Hille, 1992). Specific expression of the Kv3.3b channel cDNA in mature Purkinje cells may be essential in the development of mature physiologic function in these neurons. Since expression of this $\mathrm{K}^{+}$channel is properly regulated in mixed cultures of cerebellar neurons, it will be of interest to correlate the expression of this gene with Purkinje cell physiologic parameters using the in vitro culture system. One might expect, for example, that expression of the $\mathrm{Kv3} .3 \mathrm{~b}$ gene in mature Purkinje cells could alter their excitability and, perhaps, synaptic function.

Characterization of Kv3.3b cDNAs and mapping onto the genomic clone establish that the deduced $m R N A$ reported in the original study of the Kv3.3 gene (Ghanshani et al., 1992) is probably not correct. Thus, the 3 ' sequences thought to comprise part of the Kv3.3 mRNA, based on their colinearity with partial cDNAs in the Kv3.3 genomic clones and on studies of alternative splicing of the Kv3.1 gene (Luneau et al., 1991; Ghanshani et al., 1992), are not expressed as mature mRNA in cerebellum (Fig. 2). However, our experiments do not rule out alternative splicing as a mechanism for generating $\mathrm{K}^{+}$channel diversity from the Kv3.3 gene. Rather, we believe from characterization of additional $\mathrm{Kv} 3.3$ mRNAs that alternative transcripts arise from differential splicing of the fourth $\mathrm{Kv} 3.3$ exon. Further studies will be required to define these alternative transcripts preciscly and establish their functional consequences. This secms particularly important given the widcspread occurrence of alternative splicing in $\mathrm{K}^{+}$channel genes and the potential for very subtle regulation of neuronal physiology resulting from the increased complexity of $\mathrm{K}^{+}$channels arising as a result of alternative splicing (Jan and Jan, 1990; Salkoff et al., 1992).

The timing of expression of Kv3.3b mRNA in Purkinje cells coincides with the final stage of their differentiation. Kv3.3b mRNA is first detected between P8 and P10, as granule cells migrate from the external germinal layer to the internal granule layer where they terminally differentiate. It is during this time that Purkinje cells establish synapses with granule cell parallel fibers. Taken together with the aberrant morphology of Purkinje cells that develop in agranular cerebellar cortex (see introductory remarks), it seems probable that expression of this gene is regulated by epigenetic mechanisms involving interactions between Purkinje cells and granule cells. Definition of sequences regulating Kv3.3b mRNA expression in Purkinje cells, and the cognate transcription factors involved in this regulation, will provide an important avenue toward characterization of signal transduction pathways regulated by granule cell-Purkinje cell interactions.

\section{References}

Ausubel FM, Brent R, Kingston RE, Moore DD, Smith JA, Seidman JG. Struhl K, eds (1987) Current protocols in molecular biology. New York: Wiley.

Aviv H, Leder P (1972) Purification of biologically active globin messenger RNA by chromatography on oligothymidylic acid cellulose. Proc Natl Acad Sci USA 69:1408-1412.

Baird DH, Hatten ME, Mason C (1992) Cerebellar target neurons provide a stop signal for afferent neurite extension in vitro. J Ncurosci 12:619-634.

Berry M, Bradley P (1976) The growth of the dendritic trees of Purkinje cells in irradiated agranular cerebellar cortex. Brain Res 116:361-387.

Bradley P, Berry M (1978) The Purkinje cell dendritic tree in mutant mouse cerebellum. A quantitative Golgi study of weaver and staggerer mice. Brain Res 142:135-141.

Brochu G, Maler L, Hawkes R (1990) Zebrin II: a polypeptide antigen expressed selectively by Purkinje cells reveals compartments in rat and fish cerebellum. J Comp Neurol 291:538-552.

Butler A, Wei AG, Salkoff L (1990) Shal, Shab, and Shaw: three genes encoding potassium channels in Drosophila. Nucl Acids Res 18:21732174.

Cathala G (1983) Laboratory methods, a method for isolation of intact translationally active ribonuclcic acid. DNA 2:32-35.

Chomczynski P, Sacchi N (1987) Single-step method of RNA isolation by acid guanidinium thiocyanate-phenol-chloroform extraction. Anal Biochem 162:156-159.

Cohen-Cory S, Dreyfus CF, Black IB (1991) NGF and excitatory neurotransmitters regulate survival and morphogenesis of cultured cerebellar Purkinje cells. J Neurosci 11:462-471.

Feinberg AP, Vogelstein B (1983) A technique for radiolabelling DNA restriction endonuclease fragments to high specific activity. Anal Biochem 132:6-13.

Ghanshani S, Pak M, McPherson JD, Strong M, Dethlefs B, Wasmuth JJ, Salkoff L, Gutman GA, Chandy KG (1992) Genomic organization, nucleotide sequence, and cellular distribution of a Shaw-related potassium channel gene, $\mathrm{K} v 3.3$, and mapping of $\mathrm{K} v 3.3$ and Kv3.4 to human chromosomes 19 and 1. Genomies 12:190-196.

Groslin K, Banker GA, eds (1991) Culturing nerve cells, p 102. Cambridge, MA: MIT Press.

Hatten ME (1985) Neuronal regulation of astroglial morphology and proliferation in vitro. J Cell Biol 100:384-396.

Hatten ME, Sidman RL (1978) Cell reassociation behavior and lectininduced agglutination of embryonic mouse cells from different brain regions. J Exp Cell Res 113:111-125.

Hawkes R, Colonnier M, Leclerc N (1985) Monoclonal antibodies reveal sagittal banding in rodent cerebellar cortex. Brain Res 333: 359-365.

Herndon RM, Margolis G, Kilham L (1971a) The synaptic organization of the malformed cerebellum induced by perinatal infection with the feline panleukopenia virus (PLV). I. Elements forming the cerebellar glomeruli. J Neuropathol Exp Neurol 30:196-205.

Herndon RM, Margolis G, Kilham L (1971b) The synaptic organization of the malformed cerebellum induced by perinatal infection with the feline panleukopenia virus (PLV). II. The Purkinje cell and its afferents. J Neuropathol Exp Neurol 30:557-570.

Herndon RM, Seil FJ, Seidman C (1981) Synaptogenesis in mouse cerebellum: a comparative in vivo and tissue culture study. Neuroscience $6: 2587-2598$.

Hille B (1992) Ionic channels of excitable membranes. Sunderland. MA: Sinauer.

Hirano A, Dembitzer HM (1973) Cerebellar alterations in the weaver mouse. J Cell Biol 56:478-486.

Huynh TV, Young RA, Davis RW (1985) Constructing and screening cDNA libraries in $\lambda g t 10$ and $\lambda g t 11$. In: DNA cloning: a practical approach, Vol I (Glover DM, ed), pp 49-78. Oxford: IRL.

morphology. $d-f$ are taken after $14 \mathrm{~d}$ in vitro. High levels of expression are detected in a subset of cells with neuronal morphology (compare $d$ and $f)$. The expressing cells are calbindin positive (compare $e$ and $f$ ) and have morphology characteristic of developing Purkinje cells $(e) . g-i$ are taken after $21 \mathrm{~d}$ in vitro. High levels of expression are maintained in a subset of cells with neuronal morphology (compare $g$ and $i$ ). The expressing cells are calbindin-positive (compare $h$ and $i$ ) and have features typical of mature Purkinje cells, including a highly branched dendritic arbor $(h)$. $j-l$ are controls taken after $14 \mathrm{~d}$ in vitro. Many cells with neuronal and non-neuronal morphology are visible in phase $(j)$, including calbindin-positive cells $(k)$, but little or no hybridization is detected using the sense 8118 probe $(l)$. 
Ingram VI, Ogren MP, Chatot CL, Grossels JM, Owens BB (1985) Diversity among Purkinje cells in the mouse cerebellum. Proc Natl Acad Sci USA 82:7131-7135.

Kuhar SG, Feng L, Vidan S, Ross MF, Hatten ME, Heintz N (1993) Changing patterns of gene expression define four stages of cerebellar granule neuron differentiation. Development 117:97-104.

Jan LY, Jan YN (1990) How might the diversity of potassium channels be generated? Trends Neurosci 13:415-419.

Koh S, Oyler GA, Higgins GA (1989) Localization of nerve growth factor receptor messenger RNA and protein in the adult rat brain. Exp Neurol 106:209-221.

Luneau CJ, Williams JB, Levitan ES, Oliva C, Smith JS, Antanavage J, Folander K, Stein RB, Swanson R, Kaczmarck L, Buhrow SA (1991) Alternative splicing contributes to $\mathrm{K}^{+}$channel diversity in the mammalian nervous system. Proc Natl Acad Sci IJSA 88:39323936.

McCormack T, Vega-Saenz De Miera EC, Rudy B (1990) Molecular cloning of a mcmber of a third class of Shaker family $\mathrm{K}^{+}$channel genes in mammals. Proc Natl Acad Sci USA 87:5227-5231.

Miale IL, Sidman RL (1961) An autoradiographic analysis of histogenesis in the mouse cerebellum. Exp Neurol 4:277-296.

Mullen RJ, Eicher EM, Sidman RL (1976) Purkinje cell degeneration, a new neurological mutation in the mouse. Proc Natl Acad Sci USA 73:208-212.

Pearson WR, Lipman DJ (1988) Improved tools for biological sequence comparison. Proc Natl Acad Sci USA 85:2444-2448

Pioro EP, Cuello AC (1990) Distribution of nerve growth factor receptor-like immunoreactivity in the adult rat central nervous system. Effect of colchicine and corrclation with the cholinergic system. II Brainstem, cerebellum and spinal cord. Neuroscience 34:89-110.

Rakic P, Sidman RL (1973a) Sequence of developmental abnormalities leading to granule cell deficit in cerebellar cortex of weaver mutant mice. J Comp Neurol 152:103-132.

Rakic P, Sidman RL (1973b) Organization of cerebellar cortex secondary to deficit of granule cells in weaver mutant mice. J Comp Neurol 152:133-162.

Ramon y Cajal S (1911) Histologie du systeme nerveux de l'home et des vertebres, Vol II. Paris: Maloine. Reprint. Madrid: Consejo Superior de Investigaciones Cientificas, 1955.

Salkoff L, Baker K, Butler A, Covarrubias M, Pak MD, Wei A (1992) An essential 'set' of $\mathrm{K}^{+}$channels conserved in flies, mice and humans. Trends Neurosci 15:161-166.
Shamley DR, Opperman LA, Buffenstein R, Ross FP (1992) Ontogeny of calbindin- $\mathrm{D}_{28 \mathrm{~K}}$ and calbindin- $\mathrm{D}_{9 \mathrm{~K}}$ in the mouse kidney, duodenum, cerebellum and placenta. Development 116:491-496.

Shimada M, I angman J (1970) Repair of the external granule layer of the hamster cerebellum after prenatal and postnatal administration of methylazoxymethanol. Teratology 3:119-134.

Sidman RL (1968) Development of interneuronal connections in brains of mutant mice. In: Physiological and biomedical aspects of nervous integration (Carlson FD, ed), pp 163-193. Englewood Cliffs, NJ: Prentice-Hall.

Sive HL, St. John T (1988) A simple subtractive hybridization technique employing photoactivatable biotin and phenol extraction. Nucl Acids Res 22:10937.

Sotelo C (1975) Dendritic abnormalities of Purkinje cells in the cerebellum of neurologic mutant mice (weaver and staggerer). In: Physiology and pathology of dendrites (Kreutzberg GW, ed), pp 335-371. New York: Raven.

Solelo C, Wassef M (1991) Cerebellar development: afferent organization and Purkinje cell heterogeneity. Philos Trans R Soc Lond [Biol] 331:307-313

Stainier DY, Gilbert W (1989) The monoclonal antibody B30 recognizes a specific neuronal cell surface antigen in the developing mesencephalic trigeminal nucleus of the mouse. J Neurosci 9:2468-2485.

Trenkner E, Sidman RL (1981) Histogenesis of mouse cerebellum in microwell cultures. J Cell Biol 75:915-940.

Tsaur ML, Sheng M, Lowenstein DH, Jan YN, Jan LY (1992) Differential expression of $\mathrm{K}^{+}$channel $\mathrm{mRNAs}$ in the rat brain and downregulation in the hippocampus following seizures. Neuron 8:10551067.

Uzman LL (1960) The histogenesis of the mouse cerebellum as studied by its tritiated thymidine uptake. J Comp Neurol 114:137-159.

Vega-Saenz de Miera E, Moreno $H$, Fruhling D, Kentros C, Rudy B (1992) Cloning of ShIII (Shaw-like) cDNAs encoding a novel highvoltage-activating, TEA-sensitive, type- $\mathrm{A} \mathrm{K}^{+}$channel. Proc $\mathrm{R} \mathrm{Soc}$ Lond [Biol] 248:9-18.

Wei A, Covarrubias M, Butler A, Baker K, Pak M, Salkoff L (1990) $\mathrm{K}+$ current diversity is produced by an extended gene family conserved in Drosophila and mouse. Science 248:599-603.

Woodward DJ, Bickett D, Chanda R (1975) Purkinje cell dendritic alterations after transient developmental injury of the external granular layer. Brain Res 97:195-214. 